\title{
The SP19 chronology for the South Pole Ice Core - Part 1: volcanic matching and annual layer counting
}

Dominic A. Winski ${ }^{1,2}$, Tyler J. Fudge ${ }^{3}$, David G. Ferris ${ }^{4}$, Erich C. Osterberg ${ }^{4}$, John M. Fegyveresi ${ }^{5}$, Jihong Cole-Dai ${ }^{6}$, Zayta Thundercloud $^{4}$, Thomas S. Cox ${ }^{7}$, Karl J. Kreutz ${ }^{1,2}$, Nikolas Ortman ${ }^{4}$, Christo Buizert ${ }^{8}$, Jenna Epifanio ${ }^{8}$, Edward J. Brook $^{8}$, Ross Beaudette ${ }^{9}$, Jeffrey Severinghaus ${ }^{9}$, Todd Sowers ${ }^{10}$, Eric J. Steig ${ }^{3}$, Emma C. Kahle ${ }^{3}$, Tyler R. Jones ${ }^{11}$, Valerie Morris ${ }^{11}$, Murat Aydin ${ }^{12}$, Melinda R. Nicewonger ${ }^{12}$, Kimberly A. Casey ${ }^{13,14}$, Richard B. Alley ${ }^{10}$, Edwin D. Waddington ${ }^{3}$, Nels A. Iverson ${ }^{15}$, Nelia W. Dunbar ${ }^{15}$, Ryan C. Bay ${ }^{16}$, Joseph M. Souney ${ }^{17}$, Michael Sigl ${ }^{18}$, and Joseph R. McConnell ${ }^{19}$

${ }^{1}$ School of Earth and Climate Sciences, University of Maine, Orono, Maine, USA

${ }^{2}$ Climate Change Institute, University of Maine, Orono, Maine, USA

${ }^{3}$ Department of Earth and Space Sciences, University of Washington, Seattle, Washington, USA

${ }^{4}$ Department of Earth Sciences, Dartmouth College, Hanover, New Hampshire, USA

${ }^{5}$ School of Earth and Sustainability, Northern Arizona University, Flagstaff, Arizona, USA

${ }^{6}$ Department of Chemistry and Biochemistry, South Dakota State University, Brookings, South Dakota, USA

${ }^{7}$ Physical Science Department, Butte College, Oroville, California, USA

${ }^{8}$ College of Earth, Ocean and Atmospheric Sciences, Oregon State University, Corvallis, Oregon, USA

${ }^{9}$ Scripps Institution of Oceanography, UC San Diego, La Jolla, California, USA

${ }^{10}$ Department of Geosciences and Earth and Environmental Systems Institute, Pennsylvania State University,

University Park, Pennsylvania, USA

${ }^{11}$ Institute of Arctic and Alpine Research, University of Colorado, Boulder, Colorado, USA

${ }^{12}$ Department of Earth System Science, UC Irvine, Irvine, California, USA

${ }^{13}$ Earth Sciences Division, NASA Goddard Space Flight Center, Greenbelt, Maryland, USA

${ }^{14}$ National Land Imaging Program, U.S. Geological Survey, Reston, Virginia, USA

${ }^{15}$ New Mexico Institute of Mining and Technology, New Mexico Bureau of Geology and Mineral Resources, Socorro, New Mexico, USA

${ }^{16}$ Physics Department, University of California, Berkeley, California, USA

${ }^{17}$ Institute for the Study of Earth, Oceans and Space, University of New Hampshire, Durham, New Hampshire, USA

${ }^{18}$ Department of Climate and Environmental Physics, University of Bern, Switzerland

${ }^{19}$ Division of Hydrologic Sciences, Desert Research Institute, Reno, Nevada, USA

Correspondence: Dominic A. Winski (dominic.winski@maine.edu)

Received: 23 May 2019 - Discussion started: 5 June 2019

Revised: 20 August 2019 - Accepted: 23 August 2019 - Published: 8 October 2019

Abstract. The South Pole Ice Core (SPICEcore) was drilled in 2014-2016 to provide a detailed multi-proxy archive of paleoclimate conditions in East Antarctica during the Holocene and late Pleistocene. Interpretation of these records requires an accurate depth-age relationship. Here, we present the SPICEcore (SP19) timescale for the age of the ice of SPICEcore. SP19 is synchronized to the WD2014 chronology from the West Antarctic Ice Sheet Divide (WAIS Divide) ice core using stratigraphic matching of 251 volcanic events. These events indicate an age of $54302 \pm 519 \mathrm{BP}$ (years before $1950)$ at the bottom of SPICEcore. Annual layers identified in sodium and magnesium ions to $11341 \mathrm{BP}$ were used to interpolate between stratigraphic volcanic tie points, yielding an annually resolved chronology through the Holocene. Estimated timescale uncertainty during the Holocene is less than 18 years relative to WD2014, with the exception of the in- 
terval between 1800 to $3100 \mathrm{BP}$ when uncertainty estimates reach \pm 25 years due to widely spaced volcanic tie points. Prior to the Holocene, uncertainties remain within 124 years relative to WD2014. Results show an average Holocene accumulation rate of $7.4 \mathrm{~cm} \mathrm{yr}^{-1}$ (water equivalent). The time variability of accumulation rate is consistent with expectations for steady-state ice flow through the modern spatial pattern of accumulation rate. Time variations in nitrate concentration, nitrate seasonal amplitude and $\delta^{15} \mathrm{~N}$ of $\mathrm{N}_{2}$ in turn are as expected for the accumulation rate variations. The highly variable yet well-constrained Holocene accumulation history at the site can help improve scientific understanding of deposition-sensitive climate proxies such as $\delta^{15} \mathrm{~N}$ of $\mathrm{N}_{2}$ and photolyzed chemical compounds.

\section{Introduction}

Polar ice core records provide rich archives of paleoclimate information that have been used to advance our understanding of the climate system. One of the great strengths of ice cores is the tightly constrained dating that permits interpretation of abrupt events and comparisons of phasing among records. Therefore, a critical part of the development of any ice core record is the rigorous establishment of a depth-age relationship.

Several techniques are available to assign ages to each specific depth in an ice core. These include annual layer identification of chemical (e.g., Sigl et al., 2016; Andersen et al., 2006; Winstrup et al., 2012) and physical (e.g., Hogan and Gow, 1997; Alley et al., 1997) ice properties, identification of stratigraphic horizons as relative age markers (e.g., Sigl et al., 2014; Bazin et al., 2013; Veres et al., 2013), and glaciological flow modeling (e.g., Parrenin et al., 2004). To establish a depth-age relationship for the South Pole Ice Core (hereafter SPICEcore), we use a combination of (1) annual layer counting of glaciochemical tracers and (2) stratigraphic matching of volcanic horizons to the West Antarctic Ice Sheet (WAIS) Divide ice core timescale "WD2014" (Sigl et al., 2016; Buizert et al., 2015).

SPICEcore was drilled in 2014-2016 for the purpose of establishing proxy reconstructions of temperature, accumulation, atmospheric circulation and composition, and other Earth system processes for the last 40000 years (Casey et al., 2014). The SPICEcore record is the only ice core south of $80^{\circ} \mathrm{S}$ extending into the Pleistocene and is also located within one of the highest accumulation regions in interior East Antarctica (Casey et al., 2014). This provides the unique opportunity to develop the most highly resolved ice core record from interior East Antarctica. The South Pole is located at an elevation of $2835 \mathrm{~m}$ (Casey et al., 2014) and has a mean annual air temperature of $-50{ }^{\circ} \mathrm{C}$ (Lazzara et al., 2012). The high accumulation rate at the South Pole ( $8 \mathrm{~cm} \mathrm{yr}^{-1}$ water equivalent; Mosley-Thompson et al., 1999; Lilien et al., 2018) relative to most of interior East Antarctica permits glaciochemical measurements at a high temporal resolution. Occasional cyclonic events, particularly during winter months, bring seasonally variable amounts of sea salt, dust and other trace chemicals to the South Pole (Ferris et al., 2011; Mosley-Thompson and Thompson, 1982; Parungo et al., 1981; Hogan, 1997). Due to the favorable logistics and location at the geographic South Pole, the immediate area has been the site of several previous ice coring campaigns (e.g., Korotkikh et al., 2014; Budner and Cole-Dai, 2003; Ferris et al., 2011; Meyerson et al., 2002; MosleyThompson and Thompson, 1982). These ice cores contain records spanning the last 2 millennia, providing insight into seasonal chemistry variations and background values as well as recent snow accumulation trends.

In this paper, we focus on dating the ice itself; the dating of the gas record and the calculation of the gas-age-ice-age difference will be the subject of a future paper. The procedures used to generate the data necessary for ice core dating and the dating techniques themselves are summarized in the remainder of the paper.

\section{Measurements and ice core data}

\subsection{Measurements}

\subsubsection{Fieldwork and preparation}

Drilling began at the South Pole in the 2014/2015 austral summer season at a location $2.7 \mathrm{~km}$ from the AmundsenScott station, using the Intermediate Depth Drill designed and deployed by the U.S. Ice Drilling Program (Johnson et al., 2014). Drilling began at a depth of $5.10 \mathrm{~m}$ and reached a depth of $755 \mathrm{~m}$ in January 2015. Drilling continued during the 2015/2016 season, reaching a final depth of $1751 \mathrm{~m}$. To extend the record to the surface, a $10 \mathrm{~m}$ core was handaugered near the location of the main borehole. Ice core sections with a diameter of $98 \mathrm{~mm}$ and length of $1 \mathrm{~m}$ were packaged and shipped to the National Science Foundation Ice Core Facility (NSF-ICF) in Denver, Colorado. Each meter-long section of core was weighed and measured to calculate density and assign core depth. The cores were cut using band saws into CFA (continuous flow analysis) sticks with dimensions of $24 \mathrm{~mm} \times 24 \mathrm{~mm} \times 1 \mathrm{~m}$ and packaged in clean room grade, ultra-low outgassing polyethylene layflat tubing (Texas Technologies ULO) in preparation for the melter system at Dartmouth College. An additional $13 \mathrm{~mm} \times 13 \mathrm{~mm} \times 1 \mathrm{~m}$ stick was used for water-isotope analyses at the University of Colorado (see Jones et al., 2017, for water-isotope methods).

\subsubsection{Electrical conductivity measurements}

During core processing at the NSF-ICF, each core was cut and planed horizontally to produce a smooth, flat surface (Souney et al., 2014). Electrical conductivity measurements 
(ECMs) were made with both direct current (DC) and alternating current $(\mathrm{AC})$. We report only $\mathrm{AC}-\mathrm{ECM}$ here, as it was the primary measurement for identifying volcanic peaks; further details are provided by Fudge et al. (2016a). Multiple tracks were made at different horizontal positions across the core (typically three tracks) and then averaged together. Measurements from each meter were normalized by the median to preserve the volcanic signal while providing a consistent baseline conductance to account for variations in electrode contact.

\subsubsection{Visual measurements}

Each core was examined by John Fegyveresi in a dark room with illumination from below. For some cores, particularly for depths greater than $\sim 250 \mathrm{~m}$, side-directed tray lighting using a scatter-diffuser was more effective at revealing features. All noteworthy internal features, stratigraphy, physical properties and seasonal indicators were documented by hand in paper log books.

Previous work at the South Pole shows that coarse-grained and/or depth hoar layers form annually in late summer, often capped by a bubble-free wind crust or iced crust up to $\sim 1 \mathrm{~mm}$ thickness (Gow, 1965). We used these coarsegrained layers as the annual "picks" (noted as late summers). The stratigraphy in the core was generally uniform and wellpreserved, with the pattern identified by Gow (1965) continuing downward. The depths of all noted features were recorded to the nearest millimeter. Full details on visual layer counting are described in Fegyveresi et al. (2019).

\subsubsection{Ice core chemistry analyses}

Ice sticks were melted and samples collected at Dartmouth College using a continuous flow analysis-discrete sampling (CFA-DS) melt system (Osterberg et al., 2006). Stick ends were decontaminated by scraping with pre-cleaned ceramic (ZrO) knives. Cleaned sticks were then placed in pre-cleaned holders and melted on a melt head regulated by a temperature controller in a stand-up freezer. The melt head was made of $99.9995 \%$ pure chemical-vapor-deposited silicon carbide (CVD-SIC). CVD-SIC was chosen because of its ultra-high purity, high thermal conductivity, extreme hardness and excellent resistance to acids allowing for acid cleaning when not in use. The melt head design includes a $16 \times 16 \times 3 \mathrm{~mm}$ high tiered and rimmed inner section that was tapered with capillary slits to a center drain hole to minimize the risks of contamination from outer meltwater and wicking when melting porous firn (similar to Osterberg et al., 2006). This design provides $\mathrm{a} \geq 4 \mathrm{~mm}$ buffer between the exterior of each ice stick and the edge of the center tiered section. Flexible plastic tines aligned on the four sides of the melt head keep the ice stick centered.

A peristaltic pump drew outer, contaminated meltwater away from the outer section through four waste lines. A sec- ond peristaltic pump drew clean meltwater from the central, tiered section of the melt head to a debubbler. The debubbler consisted of a short section of porous expanded PTFE tubing (Zeus Aeos 0000143895) and utilized pump pressure to force air through the tubing walls. The debubbled melt stream entered a splitter where it was separated into three fractions: one for major ion analyses, another for trace element analyses, and a third that passed through a particle counter and size analyzer (Klotz Abakus), an electrical conductivity meter (Amber Science 3084), and a flowmeter (Sensirion SLI2000) before final collection in vials (Fig. 1). Samples were collected in cleaned vials using Gilson FC204 fraction collectors (cleaning procedures described in Osterberg et al., 2006). Samples were capped and kept frozen until additional analysis.

Core depths corresponding to each sample were tracked using custom software expanding on the concept of depthpoint tracking developed by Breton et al. (2012). Simply, software tracks each depth point in the core as it progresses through the CFA-DS system until it reaches each collection vial. This is accomplished by using a combination of melt rate, flow rates and system line volumes. Melt rates were measured with a weighted rotary encoder tracking displacement as the ice stick melts. Flow rates were measured by either an electronic flow meter or by calibrating the volume per revolution of each peristaltic pump tubing piece. Fraction collector advancements were made automatically based on melt rate, ice density (in firn), and the required sample volume and frequency. In addition, the software collected data from the inline particle counter and electronic conductivity meter. This system is capable of producing high-resolution, ultra-clean samples and has been used successfully in previous studies (e.g., Osterberg et al., 2017; Winski et al., 2017; Breton et al., 2012; Koffman et al., 2014). Samples corresponding to the top and bottom of each stick were assigned depths equal to the top and bottom depths measured at NSFICF, with intervening samples scaled linearly by the ratio of the NSF-ICF core lengths over the lengths measured by the depth encoder. This ensures that our data remain consistent with other SPICEcore datasets and there is no possibility of drift due to scraping core breaks, measurement or encoder errors.

Discrete ion chemistry samples were collected every $1.1 \mathrm{~cm}$ on average for the upper $800 \mathrm{~m}$ (Holocene) portion of the core and every $2.4 \mathrm{~cm}$ on average for older ice. In total, 112843 samples were collected and analyzed using a Thermo Fisher Dionex ICS-5000 capillary ion chromatograph to determine the concentrations of the following major ions: nitrate, sulfate, chloride, sodium, potassium, magnesium and calcium. Liquid conductivity, particle concentration and particle size distribution measurements were taken continuously with an effective resolution of $3 \mathrm{~mm}$. 


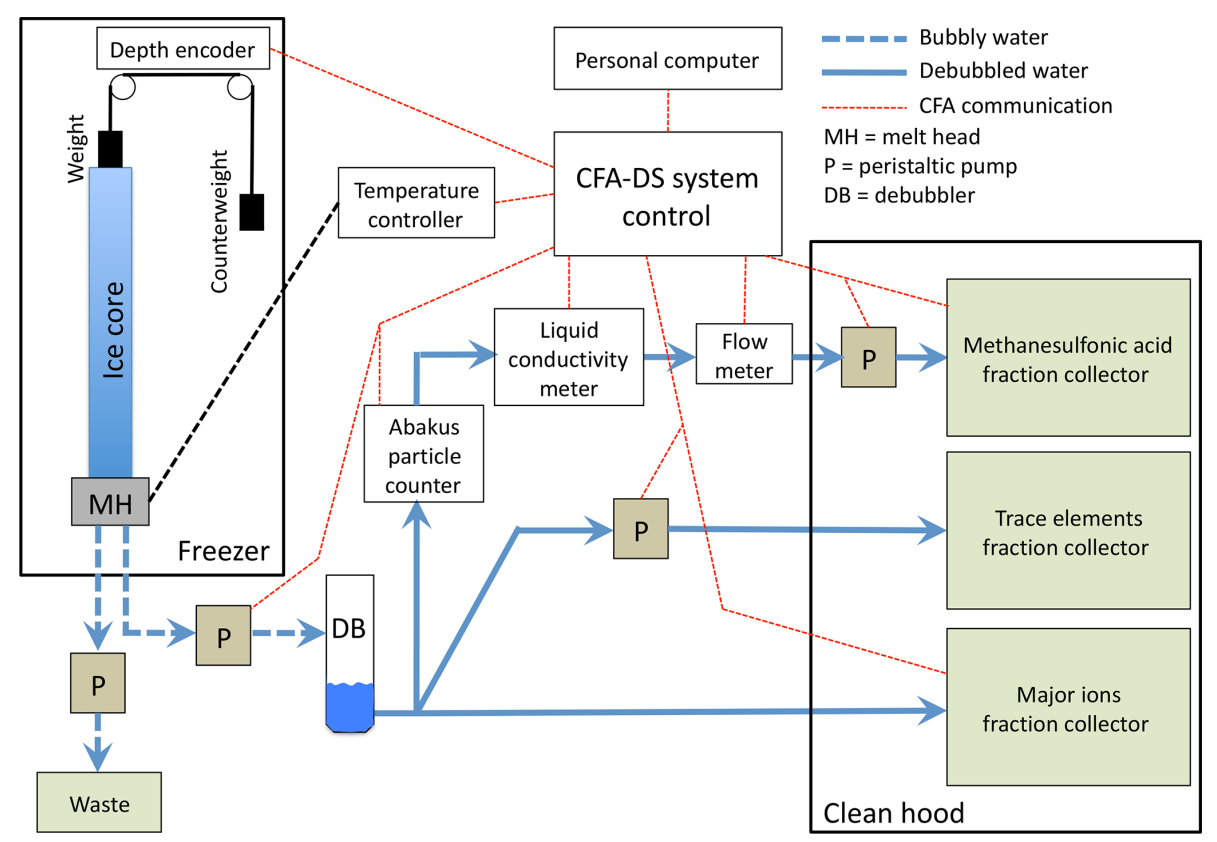

Figure 1. A schematic representation of the Dartmouth ice core melter system.

\subsubsection{Chemistry characteristics of SPICEcore}

Previous research at the South Pole has shown that major sea salt ions $\left(\mathrm{Cl}^{-}, \mathrm{Na}^{+}, \mathrm{Mg}^{2+}\right)$ have winter maxima and summer minima when compared with the position of summer depth hoar layers (Cole-Dai and Mosley-Thompson 1999; Ferris et al., 2011). The same conclusion was reached through comparisons with seasonal isotopic fluctuations: sodium and magnesium peaks coincide with seasonal water-isotope minima (Legrand and Delmas 1984; Whitlow et al., 1992). These observations are consistent with sea salt aerosol measurements collected at the South Pole that demonstrate large sodium influx during winter months (Bodhaine et al., 1986; Bergin et al., 1998). The same seasonal pattern of sea salt deposition has been observed in Holocene strata of the WAIS Divide ice core (Sigl et al., 2016) and in other Antarctic ice cores (Kreutz et al., 1997; Curran et al., 1998; Wagenbach et al., 1998; Udisti et al., 2012). In the uppermost firn, seasonal chemistry is also influenced by the operation of South Pole station and its associated logistics (Casey et al., 2017).

In SPICEcore, sampling resolution is sufficiently high to consistently detect annual cyclicity in glaciochemistry throughout the Holocene. Clear annual signals are present in several glaciochemical species to a depth of $798 \mathrm{~m}$ (approximately $11341 \mathrm{BP}$ ), with the most prominent in sodium and magnesium (Figs. 2-3), which covary $(r=0.95 ; p<0.01)$ and have coherent annual maxima and minima. Sulfate, chloride, AC-ECM, liquid conductivity, particle count and visual stratigraphy all exhibit discernable annual cyclicity.

The South Pole has long been recognized as a favorable location for identifying volcanic events, reflected by previ- ous work on South Pole paleovolcanism (Ferris et al., 2011; Delmas et al., 1992; Budner and Cole-Dai, 2003; Cole-Dai et al., 2009; Baroni et al., 2008; Cole-Dai and Thompson, 1999; Palais et al., 1990). Volcanic events in SPICEcore are evident as peaks in sulfate and ECM rising well above background values. Within the Holocene, the median annual sulfate maximum is $60 \mathrm{ppb}$. This background level increases deeper in the core to values as high as $131 \mathrm{ppb}$ between 18 and $26 \mathrm{ka}$, despite the lack of annual resolution during the Pleistocene. In contrast, sulfate concentration in volcanic events regularly exceeds $200 \mathrm{ppb}$ with occasional concentrations as high as $1000 \mathrm{ppb}$ for very large signals. For example, the pair of eruptions in 135 and $141 \mathrm{BP}$ (1815 and $1809 \mathrm{CE})$, attributed to Tambora and Unknown in previous Antarctic studies (Delmas et al., 1992; Cole-Dai et al., 2000; Sigl et al., 2013), have peak sulfate concentrations of 518 and $281 \mathrm{ppb}$, respectively, emerging well above seasonal background values of $60 \mathrm{ppb}$.

\section{SPICEcore dating methods}

\subsection{Approach}

The SPICEcore (SP19) timescale was developed by combining annual layer counting with volcanic event matching between SPICEcore and the WAIS Divide chronology. We identified 251 volcanic tie points that are clearly visible in both SPICEcore and WAIS Divide (Sigl et al., 2016). These tie points link SP19 with the WAIS Divide chronology, resulting in one of the most precisely dated interior East Antarctic records. Above 798 m, ages are interpolated between volcanic tie points using layer counts. Below 


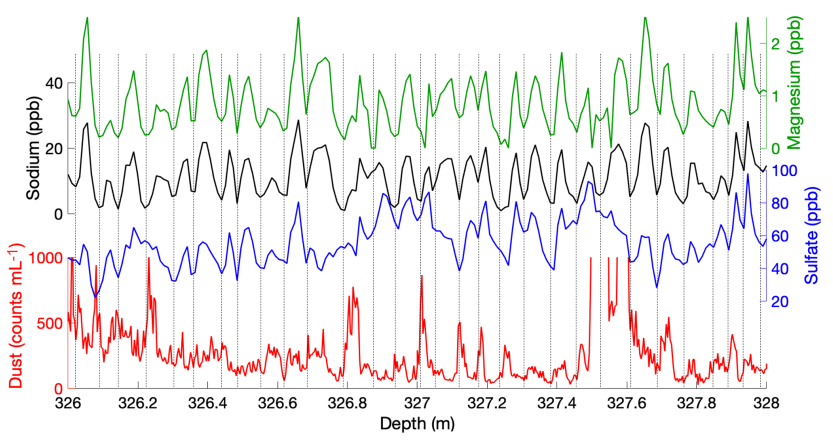

Figure 2. Example of annual layering in a representative segment of SPICEcore. Depicted are magnesium (green) and sodium (black) concentrations showing nearly identical variations and clear annual cyclicity. Sulfate (blue) has consistent but less pronounced layering, and dust (red; 1 micron size bin) has occasionally visible annual layering. Vertical dashed lines show annual pick positions based on the data shown.

$798 \mathrm{~m}$, ages are interpolated between tie points by finding the smoothest annual layer thickness profile (minimizing the second derivative) that satisfies at least $95 \%$ of the tie points (following Fudge et al., 2014).

Although it is possible to create an independent, annually layer-counted SPICEcore timescale during the Holocene, we linked the entire SP19 chronology to the WAIS Divide chronology for several reasons: (1) annual layers are insufficiently thick below $798 \mathrm{~m}$ (approximately $11341 \mathrm{BP}$ ) to consistently resolve individual years, requiring synchronization to another ice core to achieve the best possible dating accuracy - tying the entire SP19 chronology to the WAIS Divide core ensures consistent temporal relationships between these two records; (2) although annual layers are remarkably well-preserved in SPICEcore chemistry, WAIS Divide has a higher accumulation rate (Banta et al., 2008; Fudge et al., 2016b; Koutnik et al., 2016) and stronger seasonality in chemical constituents (Sigl et al., 2016), producing more robust annual layering (Fig. 4); (3) it is expected that some years at the South Pole experience very low accumulation, resulting in a lack of an annually resolvable record during those years (Hamilton et al., 2004; Van der Veen et al., 1999; Mosley-Thompson et al., 1995, 1999); (4) an attempt to independently date the Holocene annual layers created drift of several percent at stratigraphic tie points. We therefore elected to anchor the SP19 timescale to WD2014 and use the annual layer counts as a means of interpolating between WD2014 tie points during the Holocene. The SP19 timescale spans $-64 \mathrm{BP}(2014 \mathrm{CE})$ to $54302 \pm 519 \mathrm{BP}$, with the annually dated Holocene section of the core extending to 11341 BP (798 m depth).

\subsection{Procedure for identifying matching events}

The matching of volcanic events in sulfate and ECM records is commonly used to synchronize ice core timescales (e.g., Severi et al., 2007, 2012; Sigl et al., 2014; Fujita et al., 2015), including the recent extension of the annually resolved WAIS Divide timescale to East Antarctic cores (Buizert et al., 2018). Volcanic matching is based on the depth pattern of events more than the magnitude of the events because the magnitude in individual ice cores can vary significantly across Antarctica depending on the location of the volcano and atmospheric transport to the ice core site. The volcanic matching between SPICEcore and WAIS Divide is based primarily on the sulfate record for SPICEcore and the combined sulfur and sulfate records for WAIS Divide (Buizert et al., 2018). AC-ECM from SPICEcore and WAIS Divide was used as a secondary data set and to fill small data gaps in the sulfate record. An example of the four data sets is shown in Fig. 5.

The volcanic matches were performed independently by two interpreters (T.J. Fudge and David Ferris) and then reconciled by one (T.J. Fudge) with concurrence from the other (David Ferris). The position of each match was defined as the inception of the sulfate rise in order to most consistently reflect the timing of the volcanic event itself. Of the final 251 tie points, 229 were identified in the sulfate data by both interpreters. Of the remaining matches, 14 were made by one interpreter in the sulfate data and at least one interpreter in the ECM data. One of the other matches was made only with ECM because of a gap in the sulfate data for SPICEcore. The last seven matches were part of sequences not initially picked by one interpreter but deemed to be sufficiently distinct from the other events in the sequence to be included.

We note that the purpose of the volcanic matching was to develop a robust SPICEcore timescale, not to assess volcanic forcing. Thus, there are many potential volcanic matches that were not included either because they did not have the same level of certainty as the final 251 matches or because they were in close proximity to the final matches and thus did not provide additional timescale constraints.

For the pre-Holocene section of the core, ages between the volcanic matches are interpolated by finding the smoothest annual layer thickness by minimizing the second derivative (Fudge et al., 2014). The goal of finding the smoothest annual layer thickness time series is to prevent sharp changes affecting the apparent duration of climate events on either side of a volcanic match point. The method allows the ages of the volcanic matches to vary within a threshold to produce a smoother annual layer thickness interpolation. The degree of smoothness was set such that $95 \%$ of the tie points are shifted by 1 year or less, which is a reasonable uncertainty on the precision of the volcanic matches. 

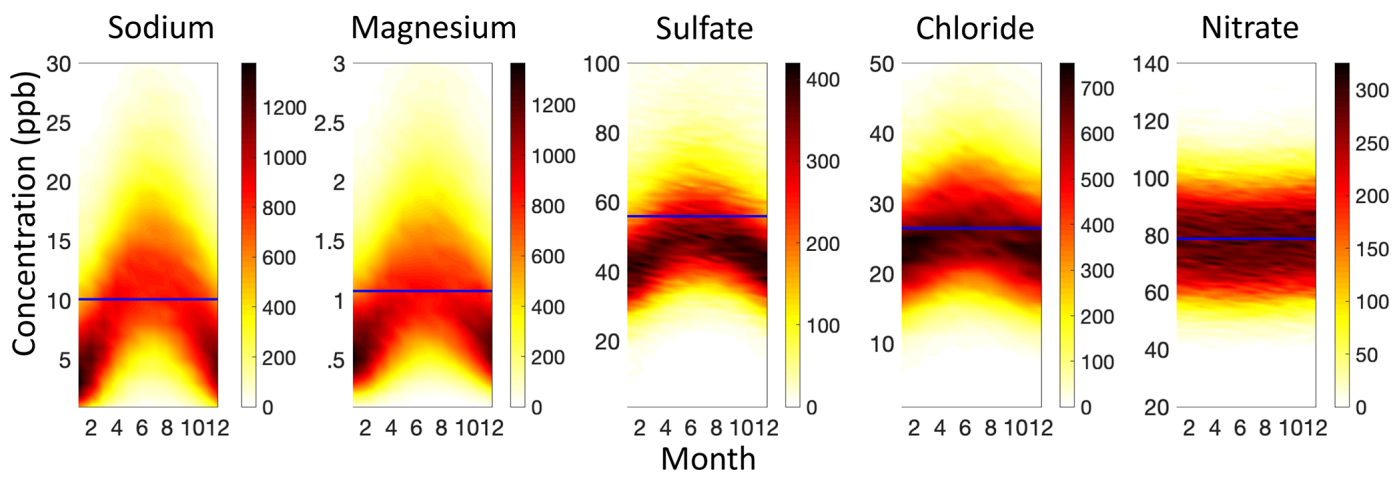

Figure 3. Seasonal variation in magnesium, sodium, sulfate, chloride and nitrate ion concentration in SPICEcore from -42 to 11341 BP (11 383 total years). In each panel, the horizontal axis is month of the year (with 0 being 1 January) from linear interpolation between mean sample depth and the timescale. The vertical axis is concentration ( $\mathrm{ppb}$ ). The color scale indicates the density of measurements within gridded month and concentration bins. Concentration bin widths are 1 month (without claiming 1 month precision) and 1 ppb except for magnesium, which is $0.1 \mathrm{ppb}$. The Holocene mean concentration of each ion is shown as a blue bar. Strong annual cyclicity is apparent in sodium and magnesium data. Annual cyclicity is weaker in sulfate, chloride and nitrate data.

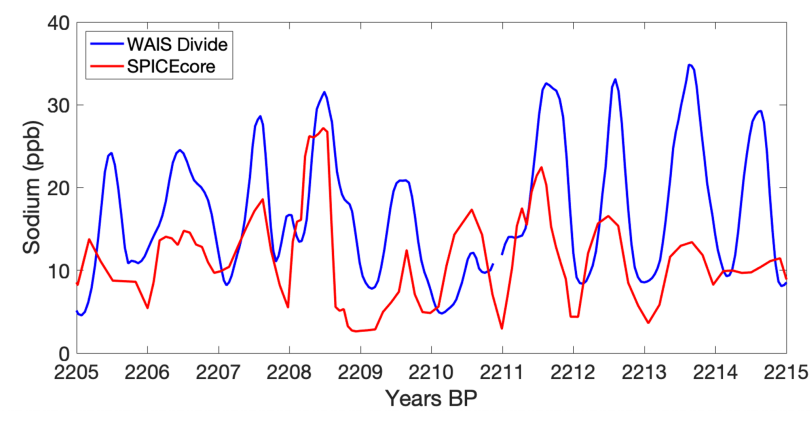

Figure 4. Annual layering of sodium in WAIS Divide (blue; Sigl et al., 2013) and SPICEcore (red). Annual layers in sodium are clear in both records but are more pronounced at WAIS Divide for most years.

\subsubsection{Annual layer interpretation}

Annual layer counting in SPICEcore was initially done independently of the volcanic matching with WAIS Divide. To minimize and quantify timescale uncertainty, five interpreters performed the layer counting independently: Dominic Winski, David Ferris, T.J. Fudge, John Fegyveresi, and Thomas Cox. Sodium and magnesium were the primary annual indicators, but electrical conductivity, dust concentration, sulfate, chloride and liquid conductivity were also helpful in delineating individual years. To remain consistent, each interpreter agreed to place the location of 1 January for each year at the sodium/magnesium minimum, consistent with previous interpretation of South Pole sea salt seasonality (e.g., Ferris et al., 2011; Bergin et al., 1998). Two examples of annual layering including the 1 January positions picked by each interpreter are shown in Fig. 6. Shown here are sections of high (a) and low (b) agreement among the five interpreters.
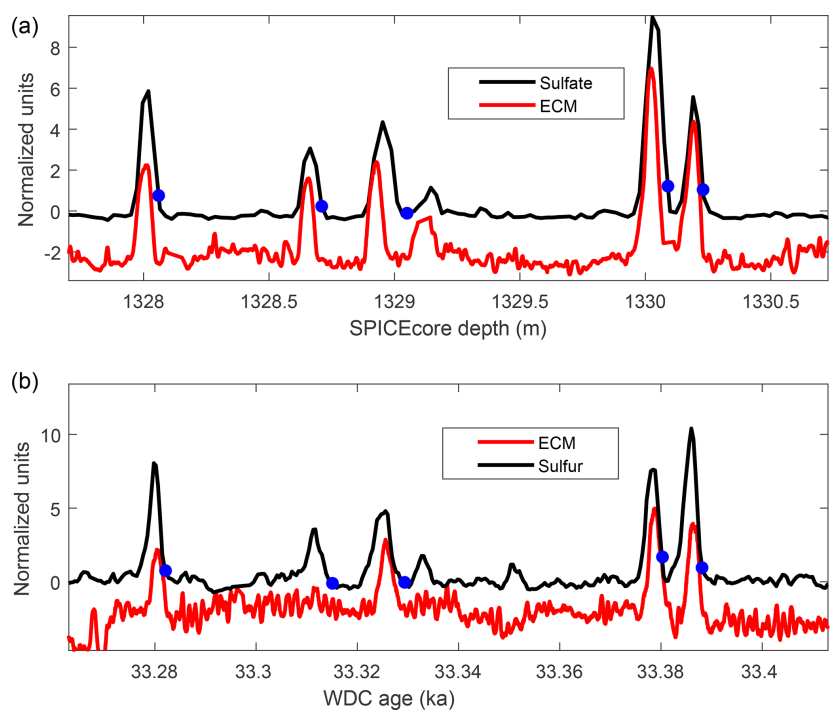

Figure 5. An example of volcanic matching between SPICEcore (a) and WAIS Divide (b). Sulfate (black) and electrical conductivity (ECM; red) are shown for both ice cores. Here, five events are shown that link specific depths in SPICEcore to known ages in WAIS Divide. The position of the tie points is chosen at the beginning of the event (blue circles). The $y$ axis values are scaled for ease of visualization and do not indicate absolute measurement values.

This procedure resulted in five independent timescales to a depth of $540 \mathrm{~m}$, containing between 6529 and 6807 years. The details of reconciling the five independent sets of layer counts are described in the Supplement. Below 540 m, only one author (Dominic Winski) continued with the layer counting once the decision to use the annual layers to interpolate between volcanic events had been made. The layer counting procedure resulted in an annually resolved timescale, fully independent of any external constraints, to a depth of 798 . 
Above $798 \mathrm{~m}, 86$ volcanic tie points were identified, producing 85 intervals within which a known number of years must be present. To make the layer-counted timescale consistent with these tie points, years were added or subtracted, as necessary, within each interval such that the layer-counted timescale passed through each tie point within \pm 1 year of its age, linking SPICEcore with the WAIS divide chronology. Procedural details for adding and subtracting layers by interval are discussed in the Supplement. In most intervals, few years needed to be added or subtracted, with the average change in years equal to $5.6 \%$ of the interval length (Holocene intervals ranged from 6 to 747 years). In certain sections layer counting consistently differed from the WAIStied timescale. The most notable example is from 228 to $275 \mathrm{~m}$ depth, where 105 years (14\%) needed to be added.

\section{Results and discussion}

\subsection{Characteristics of the timescale}

The SP19 chronology extends from 2014 CE (-64 BP) at the surface to $54302 \mathrm{BP}$ at $1751 \mathrm{~m}$ depth. The timescale and volcanic tie points are depicted in Fig. 7 with volcanic tie points pinning the timescale also shown. Annual layer thicknesses near the surface are roughly $20 \mathrm{~cm}$ thick (owing to the low density of firn), decreasing rapidly to $\sim 8 \mathrm{~cm} \mathrm{yr}^{-1}$ by the firn-ice transition. The timescale is annually resolved between -64 and $11341 \mathrm{BP}$, below which resolution varies based on the distance between tie points. Using the methods in Sect. 3.2 (Fudge et al., 2014), we report timescale values interpolated at 10-year resolution. The longest distance between tie points is 2476 years between 16348 and $19872 \mathrm{BP}$.

\subsection{Uncertainties}

In discussing uncertainty values for SP19, the reported values are uncertainty estimates rather than rigorously quantified $1 \sigma$ or $2 \sigma$ values. There are several reasons for this: (1) the chemicals used to count annual layers have similar cyclicity and are not independent; (2) while each of the five interpreters counted layers independently, they were likely employing similar strategies; (3) certain years may not be well-represented in the data, providing insufficient information for accurate dating or quantifying uncertainty; (4) volcanic events were identified in clusters such that each event is not necessarily independent; (5) it is difficult to assign a numerical index of confidence to specific volcanic tie points. Instead, we discuss timescale uncertainties as uncertainty estimates, which are intended to approximate $2 \sigma$ uncertainties but cannot be precisely defined as such. This approach follows that of Sigl et al. (2016).

We assess the SP19 timescale uncertainty with respect to the previously published WD2014 timescale (Sigl et al., 2016; Buizert et al., 2015). The absolute age uncertainty will always be equal to or greater than the uncertainty already as- sociated with WD2014 (Buizert et al., 2015; Sigl et al., 2016; Fig. 8). In addition to the uncertainty in WD2014, there is also uncertainty in our ability to interpolate between stratigraphic tie points. During the Holocene, our layer counting of sodium and magnesium concentration improves the timescale accuracy between tie points. Interpolation uncertainty can be estimated using the drift among the five different interpreters. We calculate the number of years picked by each interpreter in running intervals of 500 years in the final WD2014 synchronized timescale. Under ideal conditions, each interpreter would also pick 500 years within each interval, but on average the number of years picked by interpreters differs from the final timescale by $6.7 \%$, usually by undercounting. This is similar to the metric described in Sect. 3.3, wherein the average change in years needed to reconcile the layer counts and volcanic tie points was 5.6\% of the interval length. Here, we report the larger and more conservative value of $6.7 \%$. If our layer counting skill drifts by $\pm 6.7 \%$ while unconstrained by volcanic tie points, then the interpolation uncertainties remain within \pm 18 years of WAIS Divide throughout the Holocene with the exception of a poorly constrained interval between approximately 1800 and $3100 \mathrm{BP}$. The maximum uncertainty within the Holocene is \pm 25 years, occurring at roughly $2750 \mathrm{BP}$, where the nearest tie points are 373 years away at 2376 and $3123 \mathrm{BP}$. This relationship can be applied across the Holocene, with layers accumulating an uncertainty value equal to $6.7 \%$ of the distance to the nearest tie point (Fig. 8; blue).

Below $798 \mathrm{~m}$ depth (start of the Holocene), there were no annual layers to aid in our interpolation of the timescale, leading to larger uncertainties. Our assumption of the smoothest annual layer thickness (Fudge et al., 2014) satisfying tie points is the most accurate interpolation method in the absence of additional information, at least in Antarctic ice (Fudge et al., 2014). Using the WAIS Divide ice core as a test case, Fudge et al. (2014) estimated that the interpolation method accumulates uncertainties at a rate of $10 \%$ of the distance to the nearest tie-point, roughly $50 \%$ faster than the uncertainty of periods with identifiable annual layers. The longest interval with no volcanic constraints is between 16348 and $19872 \mathrm{BP}$. At $18110 \mathrm{BP}$, the center of the interval, the interpolation uncertainty reaches a maximum of 124 years, although uncertainties are proportionally lower in other intervals with closer volcanic tie points.

Figure 8 shows the total uncertainty estimates associated with the SP19 chronology, with interpolation uncertainties added to the published WAIS Divide uncertainties. The WD2014 and interpolation uncertainties are added in quadrature since the two sources of uncertainty are independent. The maximum estimated uncertainty in SP19 is 533 years at $34050 \mathrm{BP}$, the majority of which is attributed to uncertainties in WD2014. While it is not possible to rigorously quantify uncertainties throughout SP19, we believe these estimates provide reasonable and conservative values suitable for most paleoclimate applications. We acknowledge there 


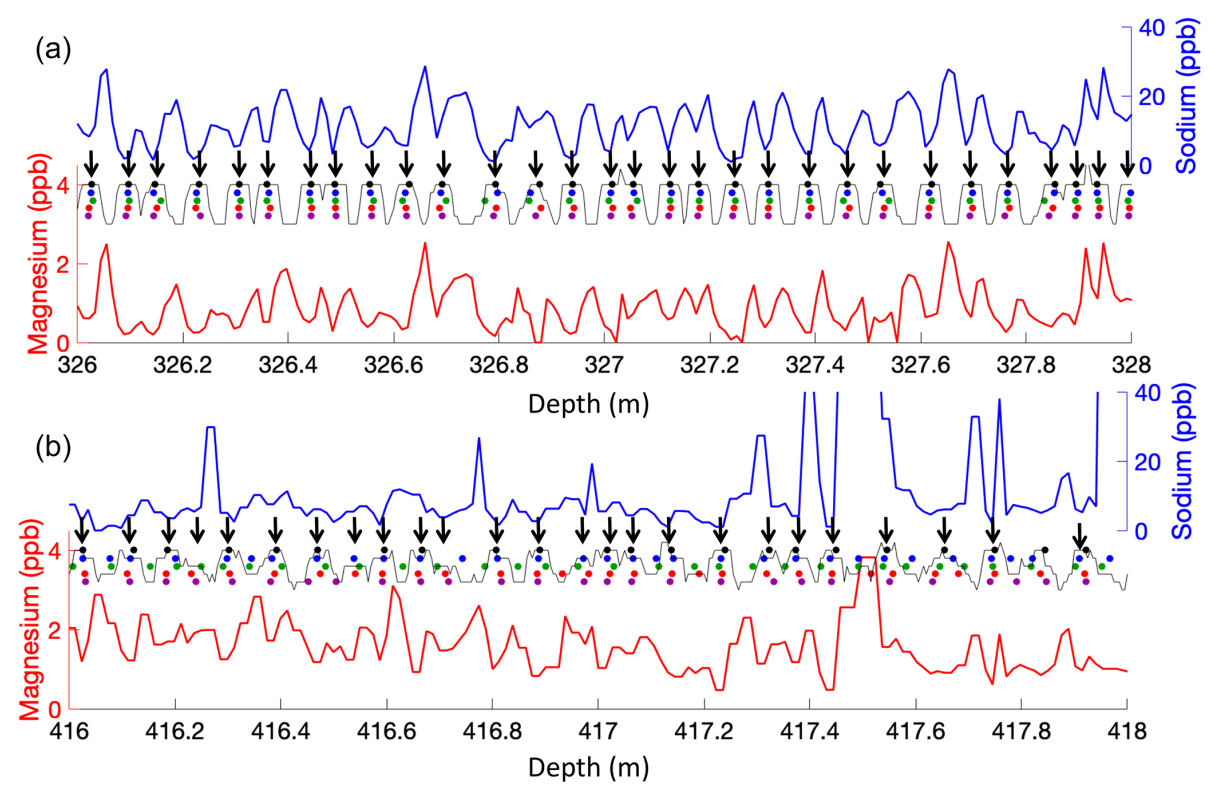

Figure 6. Representative sections of annual layer pick positions compared with magnesium (red) and sodium (blue) concentrations. Each interpreter is represented by a different color circle. Certain sections have excellent agreement among interpreters making reconciliation trivial (a), whereas other sections have poorly defined annual signals and associated disagreement among interpreters (b). The black line depicts the sum of all picks within $\pm 2 \mathrm{~cm}$; black arrows depict the final positions of the reconciled 1 January annual layer picks.

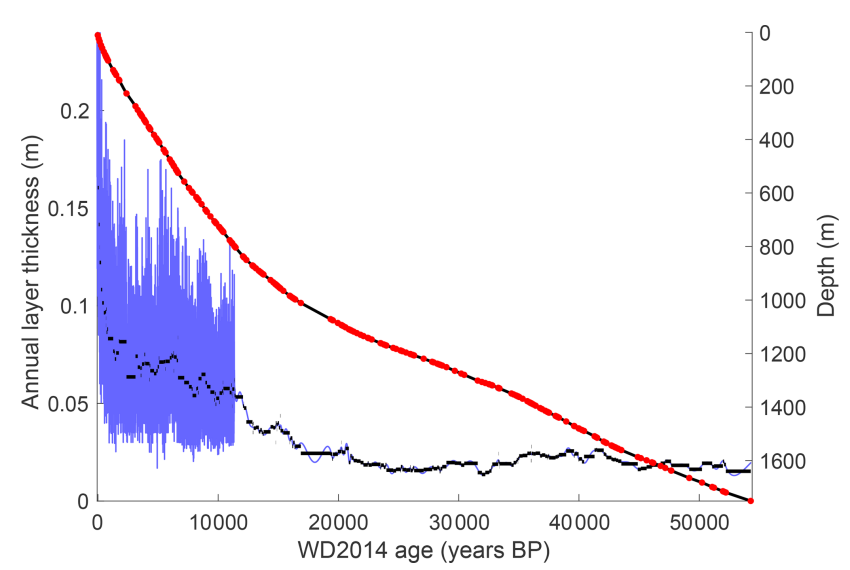

Figure 7. The SP19 timescale and layer thickness. The SP19 depthage relationship (right $y$ axis, black line) is constrained by volcanic events (red dots) extending to 54302 BP. Annual layer thicknesses (left $y$ axis, blue) are shown at annual resolution during the Holocene and as decadally interpolated thicknesses based on the smoothest annual layer thickness method (Fudge et al., 2014) during the Pleistocene. The average annual layer thickness during each volcanic interval is shown in black for comparison.

is additional uncertainty related to the accuracy of our assigned stratigraphic tie points. Because of the conservative procedures discussed in Sect. 3.1, wherein only unambiguous matches were used in linking the WAIS Divide and SPICEcore timescales, it is unlikely that any of these matches are in error. In previous work (Ruth et al., 2007), potential er- rors associated with tie points have been estimated by removing each tie point one at a time and interpolating between the new series of tie points (with one point missing). If this procedure is repeated for each tie point and for each depth, the maximum error in age resulting from the erroneous inclusion of a tie point is approximately 83 years. However, because clusters of volcanic events were used to match the WAIS Divide and SPICEcore records, each tie point is not necessarily independent. Therefore, this method is more useful at sections of widely spaced tie points with greater potential uncertainties but underestimates the uncertainties surrounding closely spaced events in SPICEcore and WAIS Divide. Examining calcium records from WAIS Divide (Markle et al., 2018) and SPICEcore shows concurrent timing in calcium variations between the two cores (Fig. S5), further supporting the choices of tie points.

\subsection{Comparison with visual stratigraphy}

Visual stratigraphy in SPICEcore provides an independent check on the glaciochemical layer counting we used to interpolate the Holocene depth-age scale between tie points. Visual layer counting was conducted to a depth of $735 \mathrm{~m}$ ( 10250 BP; Fegyveresi et al., 2019). We calculate the offset between the visual stratigraphic timescale and a linear interpolation between tie points and do the same for the chemistry layer counts (Fig. 9). If both the chemical and visual layer counting methods were capturing the true variability in layer thickness within intervals, then both would show the same structure within each interval. 

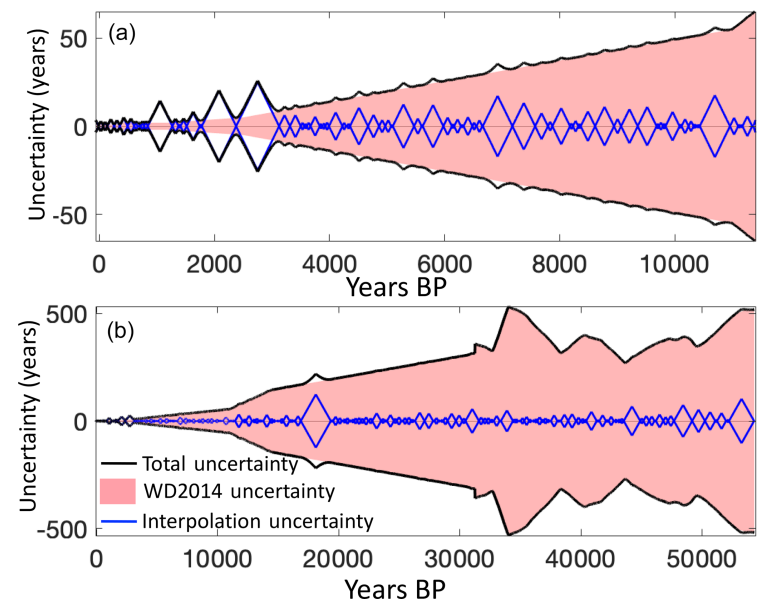

Figure 8. Uncertainty estimates in the SP19 timescale. The pink shading indicates the published uncertainty associated with the WAIS Divide timescale (Buizert et al., 2015; Sigl et al., 2016). The blue lines indicate the estimated uncertainty due to interpolation by layer counting (Holocene) and by finding the smoothest annual layer thickness history (Fudge et al., 2014; Pleistocene). Total uncertainty (black) is defined here as the root sum of the squares of the interpolation and WD2014 uncertainties. Total uncertainty estimates remain within \pm 50 years for most of the Holocene (a) but are as high as 533 years in the Pleistocene (b).

There is broad correspondence between visual and chemical stratigraphy at all depths, which, given their almost completely independent origin and measurements techniques, is highly reassuring. In detail, though, there is little highfrequency correspondence between visual and chemical layer counts below $1400 \mathrm{BP}$ ( $150 \mathrm{~m}$ depth), although a direct comparison is not possible since visible layer counts were not linked to stratigraphic tie points between 1400-2400 BP and 8400-9500 BP. Furthermore, visible layer counts were matched to the tie points within error of the WAIS Divide timescale, whereas the chemistry layer counts were forced to match within \pm 1 year of each tie point. In counting visible layers, occasional under- and overcounting of depth hoar layers within annual strata is likely, especially in deeper ice where thinning will make adjacent layers appear even closer. There were some intervals (e.g., 2000-2500 BP) in the core that appeared more homogeneous during viewing, and therefore annual layer choices have a higher level of uncertainty. Because of the differences between methodologies in matching to tie points and because of the uncertainties in visual counting below $2000 \mathrm{BP}(200 \mathrm{~m})$, we did not attempt to reconcile the visible and chemical layer counts, but instead rely only on the annual layers in the chemistry data.

Between 100 and $1400 \mathrm{BP}$, both visible and glaciochemical timescales remain remarkably coherent and do not indicate drift of more than \pm 2 years. Over this interval, the correlation between the visible and chemical layer offsets from constant annual layer thickness (red and blue curves in

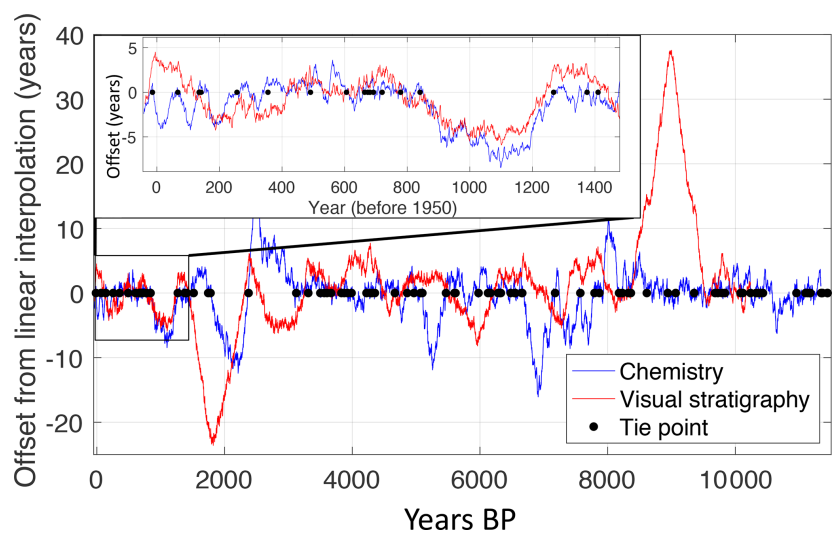

Figure 9. Comparison between visible layer (red) and chemistrybased (blue) Holocene annual timescales. Both curves are shown as residual values with respect to a linear interpolation between tie points (black circles). When the shape of the red and blue curves is similar between tie points, we infer relatively high accuracy in both methods. The region showing the closest agreement between methods is shown in the inset with both curves remaining within 2 years of each other despite a long section with no tie points (841 to $1286 \mathrm{BP})$.

Fig. 9) is 0.74 . The correlation between the two layer counting methods is as high as $r=0.85$ between the tie points at 841 and $1268 \mathrm{BP}$. The discrepancy within the top 100 years is due to the tie point at $10.58 \mathrm{~m}$, which was not included at the time of visible layer counting, as well as low layer chemical counting confidence within the firn column. There is no obvious relation between the accumulation rate and statistical agreement among methods.

\subsection{Accumulation rate history}

The SP19 timescale allows us to produce annually resolved estimates of past snow accumulation to 11341 BP (Fig. 10). We apply a Dansgaard-Johnsen model (Dansgaard et al., 1969) to estimate the amount of thinning undergone by each layer of ice. Since the entirety of the Holocene in SPICEcore is located within the top third of the core (over $1900 \mathrm{~m}$ above the bed), the challenges associated with reconstructing surface accumulation are smaller than at sites with records closer to the bed (e.g., Kaspari et al., 2008; Thompson et al., 1998; Winski et al., 2017). Radar measurements indicate a bed depth at the South Pole of $2812 \mathrm{~m}$, giving an iceequivalent thickness of $2774 \mathrm{~m}$, using the South Pole density function developed by Kuivinen et al. (1982). We used a kink height of $20 \%$ of the ice thickness and an input surface accumulation rate of $8 \mathrm{~cm} \mathrm{yr}^{-1}$ (water equivalent), consistent with the parameters used by Lilien et al. (2018). The average Holocene accumulation rate is $7.4 \mathrm{~cm} \mathrm{yr}^{-1}$ (water equivalent), in excellent agreement with results of previous studies (Hogan and Gow, $1997-7.5 \mathrm{~cm} \mathrm{yr}^{-1}$ to $2000 \mathrm{BP}$; MosleyThompson et al., $1999-6.5-8.5 \mathrm{~cm} \mathrm{yr}^{-1}$ for the late 20th 


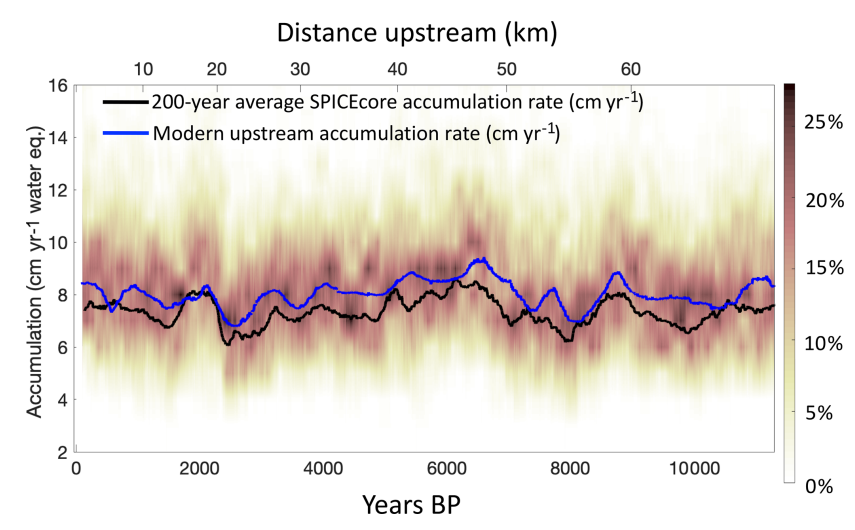

Figure 10. The Holocene accumulation rate history in SPICEcore. Shading indicates a running histogram of accumulation rate with darker colors indicative of more years at a given accumulation rate. The color axis (right) indicates percentage of years with a given accumulation rate within $1 \mathrm{~cm}$ accumulation bins across 200-year sliding intervals. The solid black line is the 200-year running mean of accumulation rate. These data are compared with modern spatial accumulation rates upstream of SPICEcore (blue; upper $x$ axis; Lilien et al., 2018).

century). The upstream flow dynamics are too complicated for a static 1-D model to accurately determine the thinning function before the Holocene.

As discussed in Lilien et al. (2018), Koutnik et al. (2016) and Waddington et al. (2007), South Pole layer thicknesses are affected by (1) spatial variability in surface accumulation being advected to the South Pole; (2) past climate-related changes in snow accumulation; and (3) post-depositional thinning due to ice flow. Thinning models can account for only the third factor. An understanding of Holocene climate history as recorded at other sites and in other indicators in SPICEcore, combined with knowledge of the modern upglacier variation in accumulation (Lilien et al., 2018), makes it clear that the Holocene SPICEcore time variations in accumulation are primarily from advection of spatial variations. Figure 10 shows the Holocene accumulation rate in SPICEcore (black) compared with geophysically derived accumulation estimates over space using ice-penetrating radar (blue, details in Lilien et al., 2018). Using the present-day surface velocity field and the inferred $15 \%$ increase in flow rate, present-day upstream surface accumulation rates were matched with corresponding ages at the SPICEcore borehole (Lilien et al., 2018). The close match between present-day near-surface accumulation rates upstream and the annual accumulation rate in SPICEcore shows that the millennial-scale signal of accumulation rate in SPICEcore is related to spatial patterns of snow accumulation upstream of the South Pole.

A striking feature in the Holocene accumulation record in SPICEcore is the sharp dip centered on 2400 BP. Annual layers were notably less clear in that portion of SPICEcore because low accumulation rates led to low sampling resolution (five to six samples per year). For instance, in the inter-

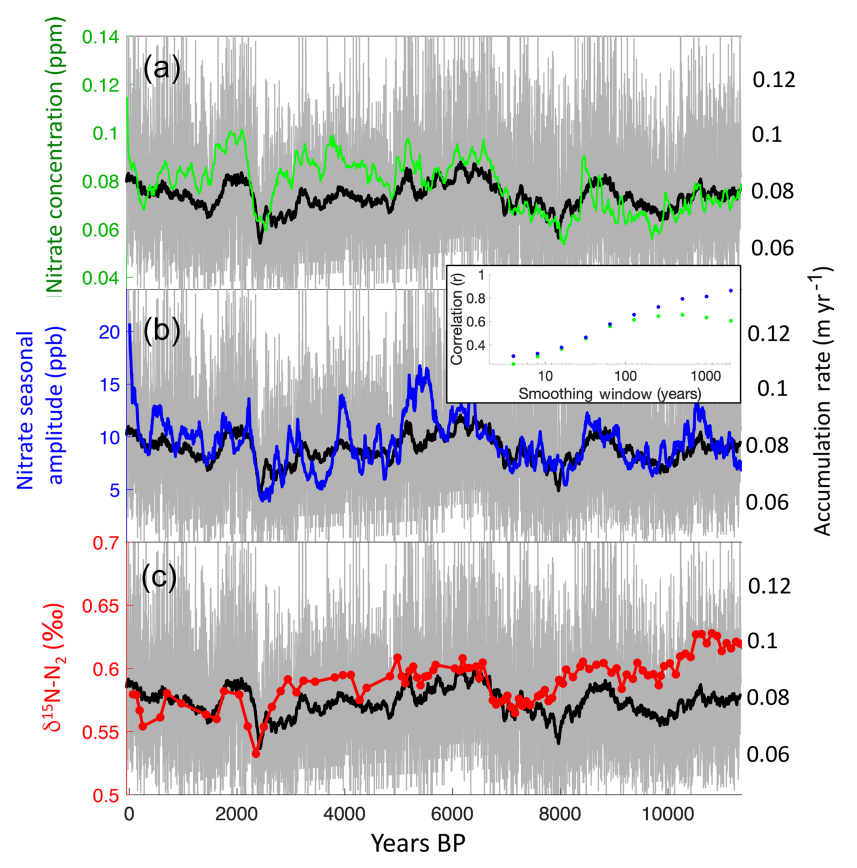

Figure 11. The Holocene accumulation rate at the South Pole compared with nitrate and $\delta^{15} \mathrm{~N}-\mathrm{N}_{2}$. In each panel, annual accumulation rates are depicted in gray, with the running 100-year mean shown in black. These results are compared with 100-year median annual values of nitrate concentration (a) and seasonal amplitude in nitrate concentration (b) as well as $\delta^{15} \mathrm{~N}-\mathrm{N}_{2}$ values (c). All three metrics exhibit shared variability on multicentennial to millennial timescales. The inset shows the correlation between accumulation rate and nitrate concentration (green) (a) and between accumulation rate and nitrate seasonal amplitude (blue) (b) against the length of the smoothing window, with both exhibiting high correlations, especially at lower frequencies.

val between 228 and $275 \mathrm{~m}$, the interpreters picked between 511 and 670 years, when 747 years are present based on the volcanic tie points. Because the undercounting of layers in the development of SP19 is coincident with low accumulation rates, we are confident that this undercounting is due to poorly resolved layers in SPICEcore rather than to erroneous tie points or errors in the WD2014 chronology.

The cause of the sharp drop in accumulation is not clear. Modern accumulation rates upstream of SPICEcore were measured using a $20 \mathrm{~m}$ deep isochron imaged with icepenetrating radar (Lilien et al., 2018). These results show lower accumulation in the location where the $2400 \mathrm{BP}$ ice originated (Fig. 10). However, the modern upstream spatial pattern of accumulation shows a decline that is both more gradual and less than half the magnitude of the $2400 \mathrm{BP}$ change in SPICEcore. It is possible that this represents a climatic signal, but we note sharp accumulation variations at this time that are not observed in the WAIS Divide core (Fudge et al., 2016b; Koutnik et al., 2016). Instead, we hypothesize that this event was most likely a transient local accumulation anomaly. Farther upstream at $\sim 75 \mathrm{~km}$ from the 


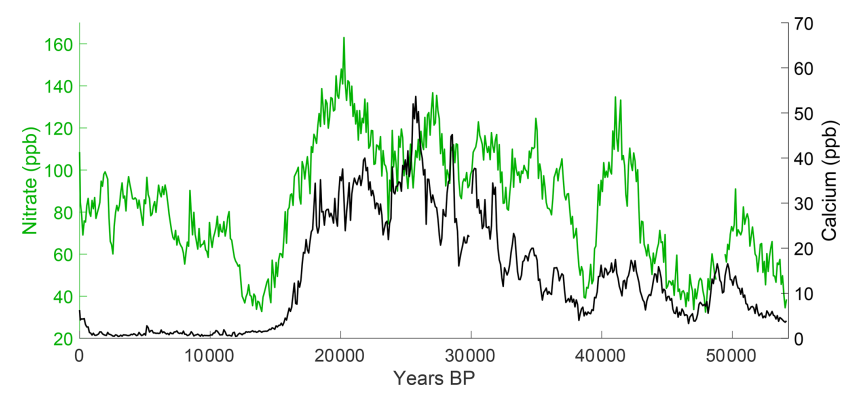

Figure 12. Nitrate and calcium concentrations in SPICEcore. There is low centennial-scale correlation $(r=0.26 ; p<0.01)$ between calcium and nitrate ions during the Holocene, when accumulation is the dominant control on nitrate concentration (Fig. 11). During the Pleistocene, centennial median nitrate and calcium are positively correlated $(r=0.80 ; p<0.01)$.

South Pole, there is an accumulation low where the rate of change is approximately $3 \mathrm{~cm} \mathrm{yr}^{-1}$ in $2 \mathrm{~km}$. With the current South Pole ice flow velocity of $10 \mathrm{~m} \mathrm{yr}^{-1}$, this could explain a $3 \mathrm{~cm} \mathrm{yr}^{-1}$ decrease in 200 years, similar to what is observed at 2400 BP. If a climate-driven accumulation anomaly did contribute to this sharp change, these anomalies do not appear to be common, as we see no other large and sustained change in the annual timescale.

On sub-centennial timescales, the effects of upstream advection of spatial accumulation patterns are likely smaller, such that annual-to-decadal patterns in snow accumulation in SPICEcore may be indicative of climate conditions. Previous studies have used a snow stake field $400 \mathrm{~m}$ to the east (upwind) of South Pole station to assess recent trends in accumulation rate with differing results. Mosley-Thompson et al. $(1995,1999)$ found a trend of increasing snow accumulation during the late 20th century, while Monaghan et al. (2006) and Lazzara et al. (2012) found decreasing snow accumulation trends between 1985-2005 and 1983-2010, respectively. No significant trends exist in the SPICEcore accumulation record within the last 50 years, although there is a significant $(p=0.046)$ increasing trend in snow accumulation in SPICEcore since 1900. Note that errors in measured firn density would influence this accumulation trend.

\subsection{Nitrate variability, $\delta^{15} \mathrm{~N}$ of $\mathrm{N}_{2}$, and accumulation}

SPICEcore nitrate concentrations provide independent support for the Holocene accumulation rate history implied by the SP19 timescale. Previous studies have recognized an association between accumulation rate and nitrate concentration among ice core sites (Rothlisberger et al., 2002). Nitrate in surface snow, exposed to sunlight, results in photolytic reactions that volatilize nitrate and release it to the atmosphere (Erbland et al., 2013; Grannas et al., 2007; Rothlisberger et al., 2000). Evaporation of $\mathrm{HNO}_{3}$ may also significantly contribute to nitrate loss in the surface snow (Munger et al., 1999; Grannas et al., 2007). Under low-accumulation

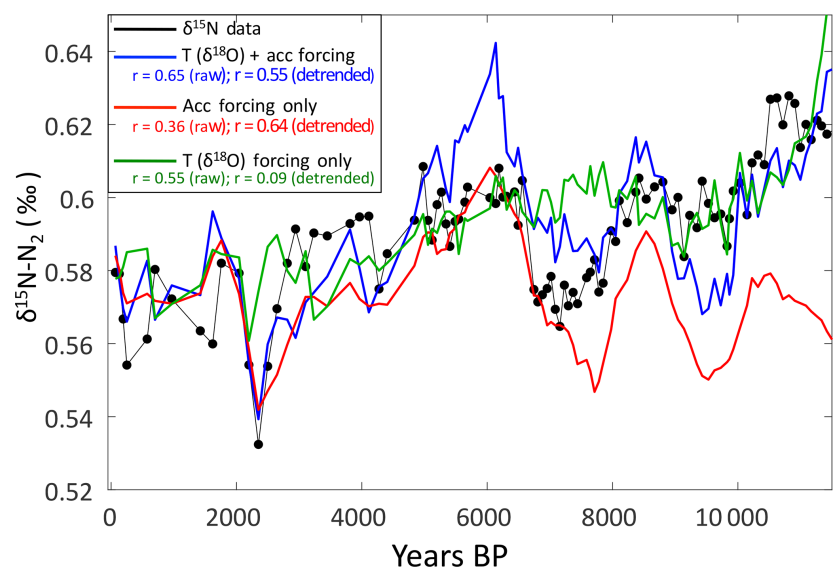

Figure 13. Results from three firn models compared with $\delta^{15} \mathrm{~N}-\mathrm{N}_{2}$ variations in SPICEcore (black). The model run incorporating only $\delta^{18} \mathrm{O}$-based temperature (green) does not capture the millennialscale variations in $\delta^{15} \mathrm{~N}-\mathrm{N}_{2}$, whereas the models using only accumulation (red) and both accumulation and $\delta^{18} \mathrm{O}$-based temperature (blue) are able to reproduce the observed millennial-scale $\delta^{15} \mathrm{~N}$ $\mathrm{N}_{2}$ changes. Correlations between the $\delta^{15} \mathrm{~N}-\mathrm{N}_{2}$ data and the three model runs are reported in the legend, with correlation coefficients calculated for both raw and linearly detrended time series.

conditions such as in East Antarctica, the amount of time snow exposed at the surface is the dominant control on nitrate concentration, such that with more accumulation, snow is more rapidly buried and retains higher nitrate concentrations (Rothlisberger et al., 2000).

There is close correspondence between accumulation rate and nitrate concentration in SPICEcore (Fig. 11a). This association is strongest on multidecadal to multicentennial timescales with correlation coefficients between accumulation rate and nitrate reaching peak values after a 512-year smoothing $(r=0.60$; Fig. 11 inset). Although the smoothing makes standard metrics of statistical significance inapplicable, the similarity between time series is expected given the previous work described above. Among sites, an inverse relationship exists between seasonal amplitude of nitrate concentration and accumulation rate. High-accumulation sites such as Summit, Greenland, exhibit strong annual nitrate layering, whereas low-accumulation sites such as Vostok $\left(\sim 2 \mathrm{~cm}\right.$ w.e. $\mathrm{yr}^{-1}$; Ekaykin et al., 2004$)$ and Dome C ( $3.6 \mathrm{~cm}$ w.e. $\mathrm{yr}^{-1}$; Petit et al., 1982) do not show annual nitrate layers at all (Rothlisberger et al., 2000). SPICEcore has much higher accumulation rates than Vostok or Dome $\mathrm{C}$ and retains weak intra-annual variability in nitrate. While minor compared with multi-annual and longer variability, nitrate seasonal cyclicity, wherein nitrate often peaks in the summer months (described in Grannas et al., 2007; Davis et al., 2004), is discernable in the SPICEcore nitrate record. As expected, the seasonal amplitude of nitrate over the Holocene closely follows nitrate concentration and accumulation rate (Fig. 11b) and is even more highly correlated with accumu- 
lation than nitrate concentration itself, especially on multicentennial to millennial timescales $(r=0.80$ at 512-year smoothing). Nitrate and accumulation rate are entirely independent variables in terms of their measurement, adding confidence to the annual layer counting and tie points underlying the SP19 chronology.

The relationship between inferred variations in accumulation rate and nitrate concentration breaks down prior to the Holocene, but a relationship between nitrate and calcium concentrations emerges. During the Pleistocene, the correlation between the centennial median of calcium and nitrate is $r=0.80(p<0.01$; Fig. 12), compared with $r=0.26$ $(p<0.01)$ during the Holocene. Rothlisberger et al. (2000, 2002) observed the same pattern at Dome $C$ and attributed it to the stabilization of nitrate through interaction with calcium and dust. They proposed that $\mathrm{CaCO}_{3}$ and $\mathrm{HNO}_{3}$ react to form $\mathrm{Ca}\left(\mathrm{NO}_{3}\right)_{2}$, which is more resistant to photolysis and consequently leads to higher concentrations of nitrate in the glacial age snowpack despite lower accumulation rates. The stabilization effect of calcium apparently overtakes photolysis and evaporation of nitrate in terms of importance only at the very high calcium concentrations as seen in the preHolocene ice.

Stable isotope ratios of atmospheric diatomic nitrogen $\left(\delta^{15} \mathrm{~N}-\mathrm{N}_{2}\right)$ in trapped air in SPICEcore show a pattern similar to accumulation rate within the Holocene (Fig. $11 \mathrm{c}$ ). $\delta^{15} \mathrm{~N}-$ $\mathrm{N}_{2}$ values were measured using the procedures described by Petrenko et al. (2006). The $\delta^{15} \mathrm{~N}-\mathrm{N}_{2}$ in ice cores is driven by gravitational enrichment and is a proxy for past thickness of the firn column (Sowers et al., 1992). Firn densification rates depend primarily on temperature and overburden pressure, with the second parameter closely linked to the accumulation rate at the site. Low temperatures and high accumulation rates both act to thicken the firn, thereby increasing $\delta^{15} \mathrm{~N}-\mathrm{N}_{2}$ (Herron and Langway, 1980; Goujon, 2003).

We perform a simple attribution study to see whether $\delta^{15} \mathrm{~N}-\mathrm{N}_{2}$ variations can be explained by reconstructed accumulation history or variable temperature. We compare three climatic scenarios in a dynamical version of the HerronLangway densification model (Buizert et al., 2014). The first uses variable temperature (from $\delta^{18} \mathrm{O}$ using a scaling ratio of $0.8 \%{ }^{\circ} \mathrm{C}^{-1}$ ) and variable accumulation (from annual layer thickness) forcing; a second uses constant temperature $\left(-51.5^{\circ} \mathrm{C}\right)$ and the variable accumulation forcing; a third uses variable temperature and constant accumulation $\left(7.8 \mathrm{~cm} \mathrm{yr}^{-1}\right)$ forcing. The correlations between the $\delta^{15} \mathrm{~N}-\mathrm{N}_{2}$ data and each model run are displayed in Fig. 13 for both raw and detrended time series. The model scenario forced by both temperature and accumulation has the best correspondence with the $\delta^{15} \mathrm{~N}-\mathrm{N}_{2}$ data $(r=0.65 ; p<0.01)$. While secular changes in temperature appear to be driving the decreasing trend in $\delta^{15} \mathrm{~N}-\mathrm{N}_{2}$, millennial-scale fluctuations in $\delta^{15} \mathrm{~N}-\mathrm{N}_{2}$ appear to be driven by accumulation, supported by the high correlation $(r=0.64 ; p<0.01)$ with the accumulation-only model run using detrended time series. In particular, a sharp drop in $\delta^{15} \mathrm{~N}-\mathrm{N}_{2}$ is present at approximately $2400 \mathrm{BP}$, coincident with (and driven by) the local minimum in accumulation. These experiments provide additional confidence in the reconstructed accumulation history. To our knowledge, these data represent the best observation of accumulation-driven $\delta^{15} \mathrm{~N}-\mathrm{N}_{2}$ variation, making it a valuable target for benchmarking firn densification model performance (Lundin et al., 2017).

\section{Summary}

The SP19 includes the last 54366 ( -64 to 54302 BP) years, and is the oldest and most well-constrained ice core timescale from the South Pole. SP19 was developed using 251 volcanic events that link the SPICEcore timescale with the WAIS Divide chronology WD2014 (Sigl et al., 2016; Buizert et al., 2015). High-resolution chemical records in SPICEcore during the Holocene provide the only annually resolved fullHolocene paleoclimate record in interior East Antarctica. Within the Holocene, SP19 uncertainties are in the range of \pm 18 years with respect to WAIS Divide, with the exception of the interval between 1800 and $3100 \mathrm{BP}$ when low accumulation and sparse volcanic controls lead to uncertainties as high as \pm 25 years. During the Pleistocene, SP19 uncertainties are inversely related to the density of tie points, with maximum uncertainties reaching \pm 124 years relative to WD2014. Results show an average Holocene accumulation rate of $7.4 \mathrm{~cm} \mathrm{yr}^{-1}$ with millennial-scale variations that are closely linked with advection of spatial surface-accumulation patterns upstream of the drill site. Nitrate concentrations, nitrate seasonal amplitude and $\delta^{15} \mathrm{~N}-\mathrm{N}_{2}$ variability are positively correlated with accumulation rate during the Holocene, providing independent confirmation of the SP19 chronology.

Data availability. The SP19 chronology, associated tie points, uncertainty estimates and supporting data sets are archived at the National Climate Data Center (https://www.ncdc.noaa.gov/paleo/ study/27690, last access: 20 September 2019, Winski et al., 2019a) and the U.S. Antarctic Program Data Center (http://www.usap-dc. org/view/dataset/601206, last access: 29 August 2019, Winski et al., $2019 \mathrm{~b}$ ) with the publication of this paper.

Supplement. The supplement related to this article is available online at: https://doi.org/10.5194/cp-15-1793-2019-supplement.

Author contributions. All authors contributed data to this study. DW, DF, EO, JCD, ZT, KK and NO measured the ice core chemistry. DW, TJF, DF, JF, EK, MA, MN, KC, and JS oversaw the ice core collection. TJF and EDW collected the ECM data. JF and RA performed the visual analysis. CB, JE, EB, RB, JS, JF and TS made the gas measurements. ES, EK, TJ and VM made the isotope measurements. DW, TJF, DF, JF and TC performed the annual layer counting. TJF and DF performed the volcanic matching with input 
from NI, ND and RB. CB, JS, TJF, ES, EB, TS, MS, JM, JCD, DF, $\mathrm{ND}$, and NI developed the WD2014 timescale. DW, TJF, DF, EO, $\mathrm{JF}$ and $\mathrm{CB}$ wrote the paper with contributions from all authors.

Competing interests. The authors declare that they have no conflict of interest.

Acknowledgements. This work was funded through US National Science Foundation grants 1443336 (Erich Osterberg), 1443105, 1141839 (Eric Steig), 1443397 (Karl Kreutz), 1443663 (Jihong Cole-Dai), 1443232 (Ed Waddington, T. J. Fudge), 1142517, 1443470 (Murat Aydin), 1443464 (Todd Sowers), 1443710 (Jeffrey Severinghaus), 1542778 (Richard Alley, John Fegyveresi), 1443472, 1643722 (Ed Brook, Christo Buizert), 1543454 (Nelia Dunbar), and 1142646 (Joseph Souney). We thank Mark Twickler and the SPICEcore Science Coordination Office for administering the project; the U.S. Ice Drilling Program for recovering the ice core; the 109th New York Air National Guard for airlift in Antarctica; the field team who helped collect the core; the members of South Pole station who facilitated the field operations; the National Science Foundation Ice Core Facility for ice core processing; and the many student researchers who produced the data underlying the SP19 timescale.

Financial support. This research has been supported by the National Science Foundation, Office of Polar Programs (grant no. $1443336,1443105,1141839,1443397,1443663,1443232$, $1142517,1443470,1443464,1443710,1542778,1443472$, $1643722,1543454,1142646)$.

Review statement. This paper was edited by Amaelle Landais and reviewed by Anders Svensson, Frédéric Parrenin, and one anonymous referee.

\section{References}

Alley, R. B., Shuman, C. A., Meese, D. A., Gow, A. J., Taylor, K. C., Cuffey, K. M., Fitzpatrick, J. J., Grootes, P. M., Zielinski, G. A., and Ram, M.: Visual-stratigraphic dating of the GISP2 ice core: Basis, reproducibility, and application, J. Geophys. Res.-Oceans, 102, 26367-26381, 1997.

Andersen, K. K., Svensson, A., Johnsen, S. J., Rasmussen, S. O., Bigler, M., Röthlisberger, R., Ruth, U., Siggaard-Andersen, M.L., Steffensen, J. P., and Dahl-Jensen, D.: The Greenland ice core chronology 2005, 15-42 ka, Part 1: constructing the time scale, Quat. Sci. Rev., 25, 3246-3257, 2006.

Banta, J. R., McConnell, J. R., Frey, M. M., Bales, R. C., and Taylor, K.: Spatial and temporal variability in snow accumulation at the West Antarctic Ice Sheet Divide over recent centuries, J. Geophys. Res.-Atmos., 113, D23102, doi:10.1029/2008JD010235, 2008.

Baroni, M., Savarino, J., Cole-Dai, J., Rai, V. K., and Thiemens, M. $\mathrm{H}$.: Anomalous sulfur isotope compositions of volcanic sulfate over the last millennium in Antarctic ice cores, J. Geophys. Res.Atmos., 113, D20112, doi:10.1029/2008JD010185, 2008.

Bazin, L., Landais, A., Lemieux-Dudon, B., Toyé Mahamadou Kele, H., Veres, D., Parrenin, F., Martinerie, P., Ritz, C., Capron, E., Lipenkov, V., Loutre, M.-F., Raynaud, D., Vinther, B., Svensson, A., Rasmussen, S. O., Severi, M., Blunier, T., Leuenberger, M., Fischer, H., Masson-Delmotte, V., Chappellaz, J., and Wolff, E.: An optimized multi-proxy, multi-site Antarctic ice and gas orbital chronology (AICC2012): 120-800 ka, Clim. Past, 9, 17151731, https://doi.org/10.5194/cp-9-1715-2013, 2013.

Bergin, M. H., Meyerson, E. A., Dibb, J. E., and Mayewski, P. A.: Relationship between continuous aerosol measurements and firn core chemistry over a 10-year period at the South Pole, Geophys. Res. Lett., 25, 1189-1192, 1998.

Bodhaine, B. A., Deluisi, J. J., Harris, J. M., Houmere, P., and Bauman, S.: Aerosol measurements at the South Pole, Tellus B, 38, 223-235, 1986.

Breton, D. J., Koffman, B. G., Kurbatov, A. V., Kreutz, K. J., and Hamilton, G. S.: Quantifying signal dispersion in a hybrid ice core melting system, Environ. Sci. Technol., 46, 11922-11928, 2012.

Budner, D. and Cole-Dai, J.: The number and magnitude of large explosive volcanic eruptions between 904 and 1865 AD: Quantitative evidence from a new South Pole ice core, Volcanism and the Earth's Atmosphere, 165-176, 2003.

Buizert, C., Cuffey, K. M., Severinghaus, J. P., Baggenstos, D., Fudge, T. J., Steig, E. J., Markle, B. R., Winstrup, M., Rhodes, R. H., Brook, E. J., Sowers, T. A., Clow, G. D., Cheng, H., Edwards, R. L., Sigl, M., McConnell, J. R., and Taylor, K. C.: The WAIS Divide deep ice core WD2014 chronology - Part 1: Methane synchronization (68-31 ka BP) and the gas age-ice age difference, Clim. Past, 11, 153-173, https://doi.org/10.5194/cp11-153-2015, 2015.

Buizert, C., Gkinis, V., Severinghaus, J. P., He, F., Lecavalier, B. S., Kindler, P., Leuenberger, M., Carlson, A. E., Vinther, B., and Masson-Delmotte, V.: Greenland temperature response to climate forcing during the last deglaciation, Science, 345, 1177 1180, 2014.

Buizert, C., Sigl, M., Severi, M., Markle, B. R., Wettstein, J. J., McConnell, J. R., Pedro, J. B., Sodemann, H., Goto-Azuma, K., and Kawamura, K.: Abrupt ice-age shifts in southern westerly winds and Antarctic climate forced from the north, Nature, 563, 681-685, 2018.

Casey, K. A., Fudge, T. J., Neumann, T. A., Steig, E. J., Cavitte, M. G. P., and Blankenship, D. D.: The $1500 \mathrm{~m}$ South Pole ice core: recovering a 40 ka environmental record, Ann. Glaciol., 55, 137146, 2014.

Casey, K. A., Kaspari, S. D., Skiles, S. M., Kreutz, K., and Handley, M. J.: The spectral and chemical measurement of pollutants on snow near South Pole, Antarctica, J. Geophys. Res.: Atmospheres, 122, 6592-6610, 2017.

Cole-Dai, J. and Mosley-Thompson, E.: The Pinatubo eruption in South Pole snow and its potential value to ice-core paleovolcanic records, Ann. Glaciol., 29, 99-105, 1999.

Cole-Dai, J., Ferris, D., Lanciki, A., Savarino, J., Baroni, M., and Thiemens, M. H.: Cold decade (AD 1810-1819) caused by Tambora (1815) and another (1809) stratospheric volcanic eruption, Geophys. Res. Lett., 36, L22703, doi:10.1029/2009GL040882, 2009. 
Cole-Dai, J., Mosley-Thompson, E., Wight, S. P., and Thompson, L. G.: A 4100-year record of explosive volcanism from an East Antarctica ice core, J. Geophys. Res.-Atmos., 105, 2443124441, 2000.

Curran, M. A. J., Van Ommen, T. D., and Morgan, V.: Seasonal characteristics of the major ions in the high-accumulation Dome Summit South ice core, Law Dome, Antarctica, Ann. Glaciol., 27, 385-390, 1998.

Dansgaard, W. and Johnsen, S. J.: A flow model and a time scale for the ice core from Camp Century, Greenland, J. Glaciol., 8, 215-223, 1969.

Davis, D., Chen, G., Buhr, M., Crawford, J., Lenschow, D., Lefer, B., Shetter, R., Eisele, F., Mauldin, L., and Hogan, A.: South Pole $\mathrm{NO}_{x}$ chemistry: an assessment of factors controlling variability and absolute levels, Atmos. Environ., 38, 5375-5388, 2004.

Delmas, R. J., Kirchner, S., Palais, J. M., and Petit, J. R.: 1000 years of explosive volcanism recorded at the South Pole, Tellus B, 44, 335-350, 1992

Ekaykin, A. A., Lipenkov, V. Y., Kuzmina, I. N., Petit, J. R., Masson-Delmotte, V., and Johnsen, S. J.: The changes in isotope composition and accumulation of snow at Vostok station, East Antarctica, over the past 200 years, Ann. Glaciol., 39, 569-575, 2004.

Erbland, J., Vicars, W. C., Savarino, J., Morin, S., Frey, M. M., Frosini, D., Vince, E., and Martins, J. M. F.: Air-snow transfer of nitrate on the East Antarctic Plateau - Part 1: Isotopic evidence for a photolytically driven dynamic equilibrium in summer, Atmos. Chem. Phys., 13, 6403-6419, https://doi.org/10.5194/acp13-6403-2013, 2013.

Fegyveresi, J. M., Fudge, T. J., Winski, D. A., Ferris, D. G., Alley R. B.: Visual Observations and Stratigraphy of the South Pole Ice Core (SPICEcore): A Chronology, ERDC/CRREL Report No. TR-19-10, ERDC-CRREL Hanover, NH, United States, https://doi.org/10.21079/11681/33378, 2019.

Ferris, D. G., Cole-Dai, J., Reyes, A. R., and Budner, D. M.: South Pole ice core record of explosive volcanic eruptions in the first and second millennia $\mathrm{AD}$ and evidence of a large eruption in the tropics around 535 AD, J. Geophys. Res.-Atmos., 116, D17308, 10.1029/2011jd015916, 2011.

Fudge, T. J., Waddington, E. D., Conway, H., Lundin, J. M. D., and Taylor, K.: Interpolation methods for Antarctic ice-core timescales: application to Byrd, Siple Dome and Law Dome ice cores, Clim. Past, 10, 1195-1209, https://doi.org/10.5194/cp-101195-2014, 2014.

Fudge, T. J., Taylor, K. C., Waddington, E. D., Fitzpatrick, J. J., and Conway, H.: Electrical stratigraphy of the WAIS Divide ice core: Identification of centimeter-scale irregular layering, J. Geophys. Res.-Earth, 121, 1218-1229, 2016a.

Fudge, T. J., Markle, B. R., Cuffey, K. M., Buizert, C., Taylor, K. C., Steig, E. J., Waddington, E. D., Conway, H., and Koutnik, M.: Variable relationship between accumulation and temperature in West Antarctica for the past 31,000 years, Geophys. Res. Lett., 43, 3795-3803, 2016b.

Fujita, S., Parrenin, F., Severi, M., Motoyama, H., and Wolff, E. W.: Volcanic synchronization of Dome Fuji and Dome C Antarctic deep ice cores over the past $216 \mathrm{kyr}$, Clim. Past, 11, 1395-1416, https://doi.org/10.5194/cp-11-1395-2015, 2015.

Goujon, C., Barnola, J. M., and Ritz, C.: Modeling the densification of polar firn including heat diffusion: Application to close- off characteristics and gas isotopic fractionation for Antarctica and Greenland sites, J. Geophys. Res.-Atmos., 108, 4792, doi:10.1029/2002JD003319, 2003.

Gow, A. J.: On the accumulation and seasonal stratification of snow at the South Pole, J. Glaciol., 5, 467-477, 1965.

Grannas, A. M., Jones, A. E., Dibb, J., Ammann, M., Anastasio, C., Beine, H. J., Bergin, M., Bottenheim, J., Boxe, C. S., Carver, G., Chen, G., Crawford, J. H., Dominé, F., Frey, M. M., Guzmán, M. I., Heard, D. E., Helmig, D., Hoffmann, M. R., Honrath, R. E., Huey, L. G., Hutterli, M., Jacobi, H. W., Klán, P., Lefer, B., McConnell, J., Plane, J., Sander, R., Savarino, J., Shepson, P. B., Simpson, W. R., Sodeau, J. R., von Glasow, R., Weller, R., Wolff, E. W., and Zhu, T.: An overview of snow photochemistry: evidence, mechanisms and impacts, Atmos. Chem. Phys., 7, 43294373, https://doi.org/10.5194/acp-7-4329-2007, 2007.

Hamilton, G. S.: Topographic control of regional accumulation rate variability at South Pole and implications for ice-core interpretation, Ann. Glaciol., 39, 214-218, 2004.

Herron, M. M. and Langway, C. C.: Firn densification: an empirical model, J. Glaciol., 25, 373-385, 1980.

Hogan, A.: A synthesis of warm air advection to the South Polar Plateau, J. Geophys. Res.-Atmos., 102, 14009-14020, 1997.

Hogan, A. W. and Gow, A. J.: Occurrence frequency of thickness of annual snow accumulation layers at South Pole, J. Geophys. Res.-Atmos., 102, 14021-14027, 1997.

Johnson, J. A., Shturmakov, A. J., Kuhl, T. W., Mortensen, N. B., and Gibson, C. J.: Next generation of an intermediate depth drill, Ann. Glaciol., 55, 27-33, 2014.

Jones, T. R., White, J. W. C., Steig, E. J., Vaughn, B. H., Morris, V., Gkinis, V., Markle, B. R., and Schoenemann, S. W.: Improved methodologies for continuous-flow analysis of stable water isotopes in ice cores, Atmos. Meas. Tech., 10, 617-632, https://doi.org/10.5194/amt-10-617-2017, 2017.

Kaspari, S., Hooke, R. L., Mayewski, P. A., Kang, S., Hou, S., and Qin, D.: Snow accumulation rate on Qomolangma (Mount Everest), Himalaya: synchroneity with sites across the Tibetan Plateau on 50-100 year timescales, J. Glaciol., 54, 343-352, 2008.

Koffman, B. G., Kreutz, K. J., Breton, D. J., Kane, E. J., Winski, D. A., Birkel, S. D., Kurbatov, A. V., and Handley, M. J.: Centennial-scale variability of the Southern Hemisphere westerly wind belt in the eastern Pacific over the past two millennia, Clim. Past, 10, 1125-1144, https://doi.org/10.5194/cp-10-11252014, 2014.

Korotkikh, E. V., Mayewski, P. A., Dixon, D., Kurbatov, A. V., and Handley, M. J.: Recent increase in Ba concentrations as recorded in a South Pole ice core, Atmos. Environ., 89, 683-687, 2014.

Koutnik, M. R., Fudge, T. J., Conway, H., Waddington, E. D., Neumann, T. A., Cuffey, K. M., Buizert, C., and Taylor, K. C.: Holocene accumulation and ice flow near the West Antarctic Ice Sheet Divide ice core site, J. Geophys. Res.-Earth, 121, 907-924, 2016.

Kreutz, K. J., Mayewski, P. A., Meeker, L. D., Twickler, M. S., Whitlow, S. I., and Pittalwala, I. I.: Bipolar changes in atmospheric circulation during the Little Ice Age, Science, 277, 1294 1296, https://doi.org/10.1126/science.277.5330.1294, 1997.

Kuivinen, K. C., Koci, B. R., Holdsworth, G. W., and Gow, A. J.: South Pole ice core drilling, 1981-1982, Antarct. Jus, 17, 89-91, 1982. 
Lazzara, M. A., Keller, L. M., Markle, T., and Gallagher, J.: Fiftyyear Amundsen-Scott South Pole station surface climatology, Atmos. Res., 118, 240-259, 2012.

Legrand, M. R. and Delmas, R. J.: The ionic balance of Antarctic snow: a 10-year detailed record, Atmos. Environ., 18, 18671874, 1984.

Lilien, D., Fudge, T. J., Koutnik, M., Conway, H., Osterberg, E., Ferris, D., Waddington, E., Stevens, C. M., and Welten, K. C.: Holocene ice-flow speedup in the vicinity of South Pole, J. Geophys. Res., 45, 6557-6565. https://doi.org/10.1029/2018GL078253, 2018.

Lundin, J. M. D., Stevens, C. M., Arthern, R., Buizert, C., Orsi, A., Ligtenberg, S. R. M., Simonsen, S. B., Cummings, E., Essery, R., and Leahy, W.: Firn Model Intercomparison Experiment (FirnMICE), J. Glaciol., 63, 401-422, 2017.

Markle, B. R., Steig, E. J., Roe, G. H., Winckler, G., McConnell, J. R., Concomitant variability in high-latitude aerosols, isotopes, and the hydrologic cycle, Nat. Geosci., 11, 853-859, 2018.

Meyerson, E. A., Mayewski, P. A., Kreutz, K. J., Meeker, L. D., Whitlow, S. I., and Twickler, M. S.: The polar expression of ENSO and sea-ice variability as recorded in a South Pole ice core, edited by: Wolff, E. W., Ann. Glaciol., 35, 430-436, 2002.

Monaghan, A. J., Bromwich, D. H., Fogt, R. L., Wang, S.-H., Mayewski, P. A., Dixon, D. A., Ekaykin, A., Frezzotti, M., Goodwin, I., and Isaksson, E.: Insignificant change in Antarctic snowfall since the International Geophysical Year, Science, 313, $827-$ 831, 2006.

Mosley-Thompson, E., and Thompson, L. G.: Nine Centuries of Microparticle Deposition at the South Pole 1, Quat. Res., 17, 1-13, 1982.

Mosley-Thompson, E., Kruss, P. D., Thompson, L. G., Pourchet, M., and Grootes, P.: Snow stratigraphic record at South Pole: potential for paleoclimatic reconstruction, Ann. Glaciol., 7, 26-33, 1985.

Mosley-Thompson, E., Thompson, L. G., Paskievitch, J. F., Pourchet, M., Gow, A. J., Davis, M. E., and Kleinman, J.: Recent increase in South Pole snow accumulation, Ann. Glaciol., 21, 131-138, 1995.

Mosley-Thompson, E., Paskievitch, J. F., Gow, A. J., and Thompson, L. G.: Late 20th Century increase in South Pole snow accumulation, J. Geophys. Res.-Atmos., 104, 3877-3886, https://doi.org/10.1029/1998jd200092, 1999.

Munger, J. W., Jacob, D. J., Fan, S. M., Colman, A. S., and Dibb, J. E.: Concentrations and snow-atmosphere fluxes of reactive nitrogen at Summit, Greenland, J. Geophys. Res.-Atmos., 104, 13721-13734, 1999.

Osterberg, E. C., Handley, M. J., Sneed, S. B., Mayewski, P. A., and Kreutz, K. J.: Continuous ice core melter system with discrete sampling for major ion, trace element, and stable isotope analyses, Environ. Sci. Technol., 40, 3355-3361, https://doi.org/10.1021/es052536w, 2006.

Osterberg, E. C., Winski, D. A., Kreutz, K. J., Wake, C. P., Ferris, D. G., Campbell, S., Introne, D., Handley, M., and Birkel, S.: 1200-Year Composite Ice Core Record of Aleutian Low Intensification, Geophys. Res. Lett., 44, 7447-7454, doi:10.1002/2017GL073697, 2017.

Palais, J. M., Kirchner, S., and Delmas, R. J.: Identification of some global volcanic horizons by major element analysis of fine ash in Antarctic ice, Ann. Glaciol., 14, 216-220, 1990.
Parrenin, F., Remy, F., Ritz, C., Siegert, M. J., and Jouzel, J.: New modeling of the Vostok ice flow line and implication for the glaciological chronology of the Vostok ice core, J. Geophys. Res.-Atmos., 109, D20102, doi:10.1029/2004JD004561, 2004.

Parungo, F., Bodhaine, B., and Bortniak, J.: Seasonal variation in Antarctic aerosol, J. Aerosol Sci., 12, 491-504, 1981.

Petit, J. R., Jouzel, J., Pourchet, M., and Merlivat, L.: A detailed study of snow accumulation and stable isotope content in Dome C (Antarctica), J. Geophys. Res.-Oceans, 87, 4301-4308, 1982.

Petrenko, V. V., Severinghaus, J. P., Brook, E. J., Reeh, N., and Schaefer, H.: Gas records from the West Greenland ice margin covering the Last Glacial Termination: a horizontal ice core, Quat. Sci. Rev., 25, 865-875, 2006.

Röthlisberger, R., Hutterli, M. A., Sommer, S., Wolff, E. W., and Mulvaney, R.: Factors controlling nitrate in ice cores: Evidence from the Dome C deep ice core, J. Geophys. Res.-Atmos., 105, 20565-20572, 2000.

Röthlisberger, R., Hutterli, M. A., Wolff, E. W., Mulvaney, R., Fischer, H., Bigler, M., Goto-Azuma, K., Hansson, M. E., Ruth, U., and Siggaard-Andersen, M.-L.: Nitrate in Greenland and Antarctic ice cores: a detailed description of post-depositional processes, Ann. Glaciol., 35, 209-216, 2002.

Ruth, U., Barnola, J.-M., Beer, J., Bigler, M., Blunier, T., Castellano, E., Fischer, H., Fundel, F., Huybrechts, P., Kaufmann, P., Kipfstuhl, S., Lambrecht, A., Morganti, A., Oerter, H., Parrenin, F., Rybak, O., Severi, M., Udisti, R., Wilhelms, F., and Wolff, E.: "EDML1": a chronology for the EPICA deep ice core from Dronning Maud Land, Antarctica, over the last 150000 years, Clim. Past, 3, 475-484, https://doi.org/10.5194/cp-3-475-2007, 2007.

Severi, M., Becagli, S., Castellano, E., Morganti, A., Traversi, R., Udisti, R., Ruth, U., Fischer, H., Huybrechts, P., Wolff, E., Parrenin, F., Kaufmann, P., Lambert, F., and Steffensen, J. P.: Synchronisation of the EDML and EDC ice cores for the last 52 kyr by volcanic signature matching, Clim. Past, 3, 367-374, https://doi.org/10.5194/cp-3-367-2007, 2007.

Severi, M., Udisti, R., Becagli, S., Stenni, B., and Traversi, R.: Volcanic synchronisation of the EPICA-DC and TALDICE ice cores for the last $42 \mathrm{kyr}$ BP, Clim. Past, 8, 509-517, https://doi.org/10.5194/cp-8-509-2012, 2012.

Severinghaus, J. P., Sowers, T., Brook, E. J., Alley, R. B., and Bender, M. L.: Timing of abrupt climate change at the end of the Younger Dryas interval from thermally fractionated gases in polar ice, Nature, 391, 141-146, 1998.

Sigl, M., McConnell, J. R., Layman, L., Maselli, O., McGwire, K., Pasteris, D., Dahl-Jensen, D., Steffensen, J. P., Vinther, B., Edwards, R., Mulvaney, R., and Kipfstuhl, S.: A new bipolar ice core record of volcanism from WAIS Divide and NEEM and implications for climate forcing of the last 2000 years, J. Geophys. Res.-Atmos., 118, 1151-1169, https://doi.org/10.1029/2012jd018603, 2013.

Sigl, M., McConnell, J.R., Toohey, M., Curran, M., Das, S.B., Edwards, R., Isaksson, E., Kawamura, K., Kipfstuhl, S., Krüger, K., Layman, L., Maselli, O.J., Motizuki, Y., Motoyama, H., Pasteris, D. R., and Severi, M.: Insights from Antarctica on volcanic forcing during the Common Era, Nat. Clim. Change, 4, 693-697, 2014.

Sigl, M., Fudge, T. J., Winstrup, M., Cole-Dai, J., Ferris, D., McConnell, J. R., Taylor, K. C., Welten, K. C., Woodruff, T. E., 
Adolphi, F., Bisiaux, M., Brook, E. J., Buizert, C., Caffee, M. W., Dunbar, N. W., Edwards, R., Geng, L., Iverson, N., Koffman, B., Layman, L., Maselli, O. J., McGwire, K., Muscheler, R., Nishiizumi, K., Pasteris, D. R., Rhodes, R. H., and Sowers, T. A.: The WAIS Divide deep ice core WD2014 chronology - Part 2: Annual-layer counting (0-31 ka BP), Clim. Past, 12, 769-786, https://doi.org/10.5194/cp-12-769-2016, 2016.

Souney, J. M., Twickler, M. S., Hargreaves, G. M., Bencivengo, B. M., Kippenhan, M. J., Johnson, J. A., Cravens, E. D., Neff, P. D., Nunn, R. M., and Orsi, A. J.: Core handling and processing for the WAIS Divide ice-core project, Ann. Glaciol., 55, 15-26, 2014.

Sowers, T., Bender, M., Raynaud, D., and Korotkevich, Y. S.: $\delta 15 \mathrm{~N}$ of $\mathrm{N}_{2}$ in air trapped in polar ice: A tracer of gas transport in the firn and a possible constraint on ice age-gas age differences, J. Geophys. Res.-Atmos., 97, 15683-15697, 1992.

Thompson, L. G., Davis, M. E., Mosley-Thompson, E., Sowers, T. A., Henderson, K. A., Zagorodnov, V. S., Lin, P. N., Mikhalenko, V. N., Campen, R. K., and Bolzan, J. F.: A 25,000-year tropical climate history from Bolivian ice cores, Science, 282, 18581864, 1998.

Torrence, C. and Compo, G. P.: A practical guide to wavelet analysis, B. Am. Meteorol. Soc., 79, 61-78, 1998.

Udisti, R., Dayan, U., Becagli, S., Busetto, M., Frosini, D., Legrand, M., Lucarelli, F., Preunkert, S., Severi, M., and Traversi, R.: Sea spray aerosol in central Antarctica, Present atmospheric behaviour and implications for paleoclimatic reconstructions, Atmos. Environ., 52, 109-120, 2012.

van der Veen, C. J., Mosley-Thompson, E., Gow, A. J., and Mark, B. G.: Accumulation At South Pole: Comparison of two 900-year records, J. Geophys. Res.-Atmos., 104, 31067-31076, 10.1029/1999jd900501, 1999.

Veres, D., Bazin, L., Landais, A., Toyé Mahamadou Kele, H., Lemieux-Dudon, B., Parrenin, F., Martinerie, P., Blayo, E., Blunier, T., Capron, E., Chappellaz, J., Rasmussen, S. O., Severi, M., Svensson, A., Vinther, B., and Wolff, E. W.: The Antarctic ice core chronology (AICC2012): an optimized multi-parameter and multi-site dating approach for the last 120 thousand years, Clim. Past, 9, 1733-1748, https://doi.org/10.5194/cp-9-17332013, 2013.

Waddington, E. D., Neumann, T. A., Koutnik, M. R., Marshall, H.P., and Morse, D. L.: Inference of accumulation-rate patterns from deep layers in glaciers and ice sheets, J. Glaciol., 53, 694$712,2007$.
Wagenbach, D., Ducroz, F., Mulvaney, R., Keck, L., Minikin, A., Legrand, M., Hall, J. S., and Wolff, E. W.: Sea-salt aerosol in coastal Antarctic regions, J. Geophys. Res.-Atmos., 103, 1096110974, 1998.

Whitlow, S., Mayewski, P. A., and Dibb, J. E.: A comparison of major chemical species seasonal concentration and accumulation at the South Pole and Summit, Greenland, Atmos. Environ. A.Gen., 26, 2045-2054, 1992.

Winski, D., Osterberg, E., Ferris, D., Kreutz, D. K., Wake, C., Campbell, S., Hawley, R., Roy, S., and Birkel, S., Introne, D., and Handley, M.: Industrial-age doubling of snow accumulation in the Alaska Range linked to tropical ocean warming, Nat. Sci. Rep., 7, 2045-2322, 2017.

Winski, D. A., Fudge, T. J., Ferris, D. G., Osterberg, E. C., Fegyveresi, J. M., Cole-Dai, J., Thundercloud, Z., Cox, T. S., Kreutz, K. J., Ortman, N., Buizert, C., Epifanio, J., Brook, E. J., Beaudette, R., Severinghaus, J., Sowers, T., Steig, E. J., Kahle, E. C., Jones, T. R., Morris, V., Aydin, M., Nicewonger, M. R., Casey, K. A., Alley R. B., Waddington, E. D., Iverson, N. A., Dunbar, N. W., Bay, R. C., Souney, J. M., Sigl, M., and McConnell, J. R.: The South Pole Ice Core (SPICEcore) SP19 Age Model, National Climate Data Center, available at: https:// www.ncdc.noaa.gov/paleo/study/27690, last access: 20 September 2019a.

Winski, D. A., Fudge, T. J., Ferris, D. G., Osterberg, E. C., Fegyveresi, J. M., Cole-Dai, J., Thundercloud, Z., Cox, T. S., Kreutz, K. J., Ortman, N., Buizert, C., Epifanio, J., Brook, E. J., Beaudette, R., Severinghaus, J., Sowers, T., Steig, E. J., Kahle, E. C., Jones, T. R., Morris, V., Aydin, M., Nicewonger, M. R., Casey, K. A., Alley R. B., Waddington, E. D., Iverson, N. A., Dunbar, N. W., Bay, R. C., Souney, J. M., Sigl, M., and McConnell, J. R.: The South Pole Ice Core (SPICEcore) chronology and supporting data, U.S. Antarctic Program (USAP) Data Center, available at: http://www.usap-dc.org/view/dataset/601206, last access: 29 August 2019b.

Winstrup, M., Svensson, A. M., Rasmussen, S. O., Winther, O., Steig, E. J., and Axelrod, A. E.: An automated approach for annual layer counting in ice cores, Clim. Past, 8, 1881-1895, https://doi.org/10.5194/cp-8-1881-2012, 2012. 